\title{
Carmellose Mucoadhesive Oral Films Containing Vermiculite/Chlorhexidine Nanocomposites as Innovative Biomaterials for Treatment of Oral Infections
}

\author{
Jan Gajdziok, ${ }^{1}$ Sylva Holešová, ${ }^{2,3}$ Jan Štembírek, ${ }^{4}$ Erich Pazdziora, ${ }^{5}$ Hana Landová, ${ }^{1}$ \\ Petr Doležel, ${ }^{1}$ and David Vetchý ${ }^{1}$ \\ ${ }^{1}$ Department of Pharmaceutics, University of Veterinary and Pharmaceutical Sciences, Palackého Trída 1-3, \\ 61242 Brno, Czech Republic \\ ${ }^{2}$ Nanotechnology Centre, VŠB-Technical University of Ostrava, 17 Listopadu 15/2172, Poruba, 70833 Ostrava, Czech Republic \\ ${ }^{3}$ T4Innovations Centre of Excellence, VŠB-Technical University of Ostrava, 17 Listopadu 15/2172, Poruba, \\ 70800 Ostrava, Czech Republic \\ ${ }^{4}$ Department of Maxillofacial Surgery, University Hospital Ostrava, 17 Listopadu 1790/5, Poruba, 70800 Ostrava, Czech Republic \\ ${ }^{5}$ Institute of Public Health Ostrava, Centre of Clinical Laboratories, Partyzánské Náměstí 7, 70200 Ostrava, Czech Republic
}

Correspondence should be addressed to David Vetchý; vetchy@email.cz

Received 24 October 2014; Revised 3 April 2015; Accepted 3 April 2015

Academic Editor: Viness Pillay

Copyright ( 2015 Jan Gajdziok et al. This is an open access article distributed under the Creative Commons Attribution License, which permits unrestricted use, distribution, and reproduction in any medium, provided the original work is properly cited.

\begin{abstract}
Infectious stomatitis represents the most common oral cavity ailments. Current therapy is insufficiently effective because of the short residence time of topical liquid or semisolid medical formulations. An innovative application form based on bioadhesive polymers featuring prolonged residence time on the oral mucosa may be a solution to this challenge. This formulation consists of a mucoadhesive oral film with incorporated nanocomposite biomaterial that is able to release the drug directly at the target area. This study describes the unique approach of preparing mucoadhesive oral films from carmellose with incorporating a nanotechnologically modified clay mineral intercalated with chlorhexidine. The multivariate data analysis was employed to evaluate the influence of the formulation and process variables on the properties of the medical preparation. This evaluation was complemented by testing the antimicrobial and antimycotic activity of prepared films with the aim of finding the most suitable composition for clinical application. Generally, the best results were obtained with sample containing $20 \mathrm{mg}$ of chlorhexidine diacetate carried by vermiculite, with carmellose in the form of nonwoven textile in its structure. In addition to its promising physicomechanical, chemical, and mucoadhesive properties, the formulation inhibited the growth of Staphylococcus and Candida; the effect was prolonged for tens of hours.
\end{abstract}

\section{Introduction}

The oral microflora is a very specific component of the human organism. It consists of aerobic and anaerobic microorganisms whose representation depends on several factors (e.g., age, composition of food, medication, lesions in the oral cavity, systemic diseases, or infections) $[1,2]$. The most common ailment affecting the oral cavity is infectious stomatitis, which is caused by factors including inadequate oral hygiene, longterm use of antibiotics, smoking, presence of dental prostheses, and immunodeficiency or systemic disease (e.g., HIV, diabetes mellitus, and oncological illnesses), which allow the overgrowth of microorganisms and subsequent outbreak of inflammation in the oral cavity. Clinical manifestations during infectious stomatitis can be very annoying for the patient and can include pain, burning in the mouth, increased salivation, taste disturbances, and reduced food intake. The treatment of these ailments is usually based on the local application of various mucosal antiseptics in the form of rinses (e.g., chlorhexidine, cetylpyridinium, and triclosan) $[3,4]$ or systemic therapy (antibiotics and antimycotics) after the clinical status deteriorates [5-7]. 
This study deals with two representatives among the wide spectrum of microorganisms that have been identified as factors that can cause infectious stomatitis: Candida albicans and Staphylococcus aureus. Fungal infections of the oral mucosa are almost exclusively represented by oral candidiasis, of which $C$. albicans is the most common infectious agent $[1,2,8]$. Depending on the severity of the disease, treatment consists of the local or systemic administration of antiseptics and azole antifungal agents, improvement of oral hygiene, and good hygiene of any infected removable dental prostheses $[9,10]$. S. aureus is another problematic pathogen. It represents one of the most common causes of nosocomial infections that manifest in the oral cavity, especially in cases in which the mucosal barriers have been breached. After 1-2 days of incubation, serous exudation occurs in the injured tissue area and the surrounding oral mucosa becomes erythematous. If local treatment is unsuccessful, sepsis is a relatively common complication [11-13]. When treating infectious stomatitis caused by either C. albicans or S. aureus, the key factor is a successful local therapy capable of dealing with the disease before it spreads into the organism. As far as the treatment of oral infections is concerned, the current market lacks any type of local, long-acting application that can enable effective therapy without systemic treatment.

A possible solution might be the application of mucoadhesive oral films (MOFs) with incorporated inorganic clay molecules that act as carriers of antibacterial or antimycotic agents, which in turn are released gradually and directly at the target area in the oral cavity. This innovative medical formulation might satisfy the conditions of application comfort and might be especially suited to provide a long-term local effect, which would improve the effectiveness of the therapy and decrease its total strain on the body.

Mucoadhesion is a specific phenomenon of creating bonds during close contact between the mucoadhesive material and a biological surface covered with a mucus layer. Modern drug formulations based on this process have recently come to the foreground of therapeutic interest [14-21]. Thin, flexible films prepared by any of the proven methods (e.g., solvent casting, hot-melt extrusion, printing, or impregnation) are promising candidates for the oral administration of many drugs in order to ensure their systemic effect or local action in the oral cavity. Owing to their advantages (prolonged residence time, providing long periods of therapeutic drug levels at disease sites, and good stability of active ingredients), mucoadhesive films or patches represent the most recently developed medical formulation for oral application. Films are generally single- or multilayered laminates, which are preferred over adhesive tablets because they are flexible and comfortable to use. Because the film is thin and nonirritating and the structural polymers are strongly mucoadhesive, only minimal changes in the patients' normal activities (e.g., eating, drinking, or speaking) are necessary. Flexible patches of various sizes can be adapted to the morphology of the oral cavity and the size of the defect $[15,18]$.

Oral films with mucoadhesive properties represent a suitable matrix for incorporating a variety of drugs, either in their common form or bound to a specific carrier. Clay minerals appear to be very promising candidates that can act as excipients or as carriers of antimicrobial drugs [22, 23]. Clay minerals are hydrated aluminium phyllosilicates with a layered structure [24, 25]. Moreover, they are naturally occurring inorganic cation exchangers, and so they may undergo ion exchange with functional molecules and/or particles through an intercalation process, particularly with basic drugs. The layered clay mineral vermiculite (Ver) becomes a promising carrier in the area of antibacterial or antimycotic compounds because its layer charge is greater than that of the most commonly used montmorillonite (Mt). Antimicrobial compounds supported on a clay mineral matrix are generally known as inorganic and/or organic antibacterial materials. Inorganic cations of heavy metals (e.g., $\mathrm{Ag}^{+}[26-28], \mathrm{Cu}^{2+}[29,30]$, and $\mathrm{Zn}^{2+}$ [31]) are the ones used most often. Although clay-based inorganic materials show high thermal stability, they also have disadvantages, such as the accumulation of harmful heavy metals, mostly in the pseudohexagonal cavities of the silicate layers, resulting in decreased antibacterial activity. In spite of their low thermal stability, the organoclay materials exhibit many advantages compared to inorganic materials, mainly regarding their organophilicity, which results in easy adherence and ability to exterminate a number of bacterial species [32-35]. The antibacterial behaviour of vermiculite-bound chlorhexidine against selected Gram-positive and Gram-negative bacterial strains has already been demonstrated $[36,37]$.

To date, a wide variety of mucoadhesive materials have been used for the development of MOFs. Mucoadhesive polymers should exhibit certain physicochemical characteristics, including hydrophilicity, viscoelastic properties, and flexibility for interpenetration with mucus and epithelial tissue based on their numerous hydrogen bond-forming groups (hydroxylic, carboxylic, sulphate, or amide) [3841]. The most used mucoadhesive polymers belong to the group of cellulose derivatives (e.g., hydroxypropyl methylcellulose, oxycellulose), acrylic derivatives, alginates, chitosan, polyoxyethylene, polyvinyl alcohol, thiolated polymers (thiomers), or materials that are able to adhere directly to the cell surface rather than to mucus [16], such as lectins or bacterial adhesives [14, 42-45].

Carboxymethyl cellulose (CMC), a derivative with carboxymethyl groups $(-\mathrm{CH} 2-\mathrm{COOH})$ bound to some of the hydroxyl groups of the glucopyranose cellulose monomers, is among the most important mucoadhesive materials from the group of cellulose derivatives. This cellulose ether is obtained by carboxymethylating cellulose with sodium chloroacetate in an alkaline environment under strictly controlled conditions [46, 47]. CMC is commercially available in many forms that differ in their degree of substitution, viscosity, particle size, molecular weight, degree of polymerization, and other parameters [48]. The degree of substitution affects a number of physicochemical parameters of CMC, including viscosity, solubility, water-absorption capacity, and biological stability, among others [49]. CMC is a nonirritating and nontoxic material suitable for both external and internal use. It is also physiologically inert and partially biodegradable. Because of the mentioned advantages, it is widely used in medicine and in the pharmaceutical industry for a variety of 
TABle 1: Composition of casting dispersions (\% w/w) (g).

\begin{tabular}{|c|c|c|c|c|c|c|}
\hline Sample & $\mathrm{NaCMC}$ & Gly & $\mathrm{Mg}^{2+} \mathrm{Ver}_{-} \mathrm{CA}$ & $\mathrm{Mg}^{2+}{ }^{2} r_{-} \mathrm{CG}$ & Water & HCMC textile \\
\hline $\bar{C}$ & 4 & 3 & - & - & ad 100 & No \\
\hline C-T & 4 & 3 & - & - & ad 100 & Yes \\
\hline 10CHDAC & 4 & 3 & 11.17 & - & ad 100 & No \\
\hline 10CHDAC-T & 4 & 3 & 11.17 & - & ad 100 & Yes \\
\hline 20CHDAC & 4 & 3 & 22.34 & - & ad 100 & No \\
\hline 20CHDAC-T & 4 & 3 & 22.34 & & ad 100 & Yes \\
\hline $10 \mathrm{CHDG}$ & 4 & 3 & - & 11.17 & ad 100 & No \\
\hline 10CHDG-T & 4 & 3 & - & 11.17 & ad 100 & Yes \\
\hline 20CHDG & 4 & 3 & - & 22.34 & ad 100 & No \\
\hline 20CHDG-T & 4 & 3 & - & 22.34 & ad 100 & Yes \\
\hline
\end{tabular}

$18 \mathrm{~mL}$ of casting dispersion was used for preparing of films with diameter of $63 \mathrm{~mm}$.

functions, including to enhance wet wound healing and to act as a laxative, gelling agent, emulsion stabilizer, thickener, binder (in solid formulations), or a carrier of polymer for the formulation of ocular inserts. The mucoadhesive properties of CMC have also recently come to the fore because they are used in the oral, ocular, nasal, pulmonary, and vaginal application of modern formulations that feature controlled drug release [50-54].

Despite the intense focus on buccal film-based systems, there are no standardized methods for evaluation of their physicomechanical and chemical properties (e.g., residence time, mucoadhesive strength, and mechanical durability). This lack of standardized evaluation methods limits the possibility of comparing obtained data and evaluating the significance of formulation and process variables on the properties of the resulting films [21]. It is often difficult or impossible to use simple statistical methods to obtain information about the influence of variables or their combinations on the properties of final MOFs. It is appropriate to make simplifications that allow the expression of a large number of variables with a smaller number of so-called latent variables to determine dependency (correlation) in a multidimensional data set. Latent variables (principal components) then represent a kind of dimension in which the effect of variables is expressed collectively. Their advantage is that they are independent (orthogonal), which greatly simplifies interpretation. Principal component analysis (PCA) is one of the oldest and most widely used multivariate methods and is used primarily for exploratory data analysis [55].

This paper follows the previously published results aimed at the evaluation of toxicological and antibacterial properties of vermiculite nanocomposites [56]. The presented study describes the unique approach of using the solvent casting or impregnation methods to prepare MOFs from carmellose (a well-established mucoadhesive polymer) with the incorporation of a nanotechnologically modified clay mineral (vermiculite) and intercalated antiseptic drugs (chlorhexidine diacetate and digluconate). We used multivariate data analysis methods to evaluate the influence of the formulation and process variables on the physicomechanical and chemical properties of MOFs. This evaluation was complemented by testing the antimicrobial and antimycotic activity of MOFs, with the aim of finding the best composition for possible clinical application.

\section{Materials and Methods}

2.1. Materials. Clay mineral vermiculite $\left(\mathrm{Mg}^{2+} \mathrm{Ver}\right)$ from Letovice (Czech Republic) was used for the experiment. $\mathrm{Mg}^{2+}$ Ver obtained from a weathered zone of the ultrabasic body of metamorphosed basalts in the Letovice complex, in the eastern part of the Bohemia Massif (Czech Republic), was milled in a planetary mill and sieved, and the fraction $<45 \mu \mathrm{m}$ was used for the experiment. This sample did not contain other mineral phases identifiable by X-ray diffraction. Its crystallochemical formula, calculated from the results of the elemental chemical analysis, was $\left(\mathrm{Si}_{3.13} \mathrm{Al}_{0.86} \mathrm{Ti}_{0.02}\right)\left(\mathrm{Mg}_{2.53} \mathrm{Fe}_{0.45} \mathrm{Al}_{0.02}\right) \mathrm{O}_{10}(\mathrm{OH})_{2}\left(\mathrm{Mg}_{0.19} \mathrm{~K}_{0.01}\right.$ $\mathrm{Ca}_{0.02}$ ) per $\mathrm{O}_{10}(\mathrm{OH})_{2}$ with a cation exchange capacity (CEC) of $140 \mathrm{cmol}(+) / \mathrm{kg}$. Chlorhexidine diacetate (abbreviated CA, $\mathrm{C}_{22} \mathrm{H}_{30} \mathrm{~N}_{10} \mathrm{Cl}_{2} \cdot 2 \mathrm{C}_{2} \mathrm{H}_{4} \mathrm{O}_{2}$, Sigma Aldrich) and chlorhexidine digluconate (abbreviated $\mathrm{CG}, \mathrm{C}_{22} \mathrm{H}_{30} \mathrm{~N}_{10} \mathrm{Cl}_{2} \cdot 2 \mathrm{C}_{6} \mathrm{H}_{12} \mathrm{O}_{7}, 20 \%$ in $\mathrm{H}_{2} \mathrm{O}$, Sigma Aldrich) were employed as active ingredients to prepare organovermiculite nanocomposites, and ethanol was used as a solvent.

Carmellose sodium was employed (NaCMC, Blanose type 7LF-PH, Ashland Aqualon Functional Ingredients, USA), as a semisynthetic cellulose derivative, as the basic mucoadhesive and film-forming structural polymer in the formulation of MOFs. In some samples (Table 1), an acid form of carmellose (HCMC; Hcel HT, Holzbecher Medical, CZ) was incorporated into the structure of the film as a nonwoven textile to improve its physicomechanical and chemical properties. In all cases, glycerol (Gly) (Kulich, CZ) acted as a plasticizer at a concentration of 3\%. Mucin from porcine stomach (Type II, Sigma-Aldrich, Co., USA) as a 5\% dispersion $(\mathrm{w} / \mathrm{w})$ in phosphate buffer $\mathrm{pH} 6.8$ according to European Pharmacopoeia [57] was used to prepare artificial mucus for the testing of mucoadhesive properties. All other chemicals used in this experiment were of analytical grade.

2.2. Designation of the Samples. The number in the sample name expresses the amount of the active ingredient in one MOF (10 versus $20 \mathrm{mg}$ ); CHDAC means abbreviation 
of used chlorhexidine diacetate, CHDAG of chlorhexidine digluconate; $\mathrm{C}$ is the control (no active ingredient) and $\mathrm{T}$ after dash means if there was nonwoven textile or not.

2.3. Preparation of Organovermiculites. The solutions of CA and CG were prepared in ethanol in concentrations according to the $0.5 \times \mathrm{CEC}$ of $\mathrm{Mg}^{2+}$ Ver and then stirred and heated with $\mathrm{Mg}^{2+}$ Ver suspended in water. After centrifugation, solid products were dried, and samples for the experiment were named $\mathrm{Mg}^{2+}$ Ver_CA and $\mathrm{Mg}^{2+}$ Ver_CG.

2.4. Preparation of Mucoadhesive Films. A four percent dispersion of NaCMC was prepared by swelling the polymer in distilled water for $24 \mathrm{~h}$ and subsequently stirring using Ultra-turrax (T 25 basic, IKA, WERKE, GmbH\&Co.KG, D) for $2 \mathrm{~min}(16,000 \mathrm{rpm})$. As a plasticizer, glycerol was added to a final concentration of $3 \%(\mathrm{w} / \mathrm{w})$ by continual mixing. $\mathrm{Mg}^{2+}$ Ver_CA and $\mathrm{Mg}^{2+}$ Ver_CG were added to the casting dispersion at two different concentrations (Table 1) to ensure that the amount of chlorhexidine in final MOFs was 10 or $20 \mathrm{mg}$, which corresponds to the dosage applied during rinsing of the oral cavity with commercially available mouthwashes. Subsequently, ten different batches of MOFs were prepared, five using the solvent casting method (samples without HCMC textile) and five using the innovative method of impregnation of the textile from acid form of carmellose (Table 1).

2.4.1. Solvent Casting Method. Using an automatic pipette (Transferpette S, range 5 to $20 \mathrm{~mL}$, Brand, UK), $18 \mathrm{~mL}$ of the prepared uniform dispersions was cast into a round plastic mold (63 mm diameter), and the solvent was left to evaporate for $24 \mathrm{~h}$ in a ventilated oven at $30^{\circ} \mathrm{C}$. Samples $(25 \times 25 \mathrm{~mm}$, $10 \times 40 \mathrm{~mm}$, and $15 \mathrm{~mm}$ diameter) of final films for testing of physicomechanical and chemical properties and in vitro antimicrobial activity were punched using steel punches.

2.4.2. Method of Impregnation. The acid form of carmellose in the form of nonwoven textile was cut into a circular shape (63 mm diameter) and placed in the casting molds. The textile was impregnated with the same amount of prepared dispersions to ensure the same concentration of active ingredients as in samples prepared using the solvent casting method. Solvent was evaporated at $30^{\circ} \mathrm{C}$ for $24 \mathrm{~h}$ in a ventilated oven, and prepared samples were the same sizes as were used for the solvent casting method.

2.5. Characterization of Vermiculite Samples. X-ray diffraction (XRD) patterns of organovermiculite samples were recorded using the RIGAKU Ultima IV diffractometer (reflection mode, Bragg-Brentano arrangement, $\mathrm{CuK} \alpha$ radiation) in ambient atmosphere under constant conditions (2$60^{\circ} 2 \theta$, scan speed $2^{\circ} / \mathrm{min}, 40 \mathrm{kV}, 40 \mathrm{~mA}$ ). The IR spectra of organovermiculite samples were obtained using the $\mathrm{KBr}$ method with a NEXUS 470 Fourier transform (FTIR) spectrometer (Thermo Nicolet, USA). The spectrometer was equipped with a Globar IR source, $\mathrm{KBr}$ beam splitter,
TABLE 2: Particle size analysis.

\begin{tabular}{lcc}
\hline Sample & $d_{50}[\mu \mathrm{m}]$ & $d_{43}[\mu \mathrm{m}]$ \\
\hline $\mathrm{Mg}^{2+}$ Ver & 28.85 & 37.43 \\
$\mathrm{Mg}^{2+}$ Ver_CA & 44.93 & 49.47 \\
$\mathrm{Mg}^{2+}$ Ver_CG & 74.15 & 82.11 \\
\hline
\end{tabular}

and DTGS detector. For each spectrum, 128 scans were obtained with resolution of $4 \mathrm{~cm}^{-1}$. Range of measurements was $400-4000 \mathrm{~cm}^{-1}$. The particle size (PS) of $\mathrm{Mg}^{2+} \mathrm{Ver}$ and organovermiculite samples was determined using laser diffraction particle size analyzer HORIBA LA-950 with two short-wavelength blue and red light sources in conjunction with forward and back-scatter detection to enhance sizing performance in the range $0.01-3000 \mu \mathrm{m}$.

The morphology of initial $\mathrm{Mg}^{2+}$ Ver and prepared organovermiculite samples was investigated by scanning electron microscope (SEM) Philips XL 30. SEM images were obtained using back-scatter detector (BSE) and accelerating voltage $20 \mathrm{kV}$.

2.6. Physicomechanical, Chemical, and Morphological Properties of MOFs. The weight of MOFs was measured on ten circular (15 mm diameter) samples selected at random from each batch, which were individually weighed on the analytical balance (KERN 870 - 13, Gottl. KERN \& Sohn GmbH, D). The results were expressed as the average weight of the film and its standard deviation.

Film thickness was evaluated by microscopic analysis using an optical microscope (STM-902 ZOOM, Opting, CZ) and colour digital camera (DFW X700, Sony, JPN). The rectangular sample of the film was vertically fixed in a holder; the microscope was focused on the edge of the film, and the sample thickness was measured at five different places on the film. This process was repeated three times per sample type.

Surface $\mathrm{pH}$ was measured using a contact $\mathrm{pH}$ meter (Flatrode, Hamilton, $\mathrm{CH}$ ). A moistened $\mathrm{pH}$ meter electrode was dipped into the MOF, and the value was recorded after stabilization (approximately $60 \mathrm{~s}$ ). The measurement was repeated three times per sample.

A modified disintegration apparatus was used to determine in vitro residence time according to Nafee et al. [58] (Figure 1). A standard basket for tablet insertion was replaced with a plastic slab that was vertically fixed to the apparatus. Oral mucosa was simulated using a cellophane membrane glued to the surface of the slab and covered with a $5 \%$ mucin dispersion $(\mathrm{w} / \mathrm{w})$ in phosphate buffer $\left(\mathrm{pH} 6.8 ; 10 \mu \mathrm{L} / \mathrm{cm}^{2}\right)$. The phosphate buffer ( $\mathrm{pH}$ 6.8) [56] was maintained at $37^{\circ} \mathrm{C}$ and used as testing medium. The slab with attached circular MOF samples (15 mm diameter) was allowed to move up and down (samples were completely immersed in the buffer solution at the lowest point and were out of the solution at the highest point.) The time necessary for complete detachment or erosion of the film from the surface was recorded (Table 2). This measurement was repeated three times per sample.

A modification of Shidhaye's method was used to evaluate the mechanical properties of the prepared films [59]. A CT3 
TABLE 3: Physical properties of prepared mucoadhesive oral films.

\begin{tabular}{lcccc}
\hline Sample & $\begin{array}{c}\text { Weight } \\
(\mathrm{mg})\end{array}$ & $\begin{array}{c}\text { Thickness } \\
(\mu \mathrm{m})\end{array}$ & Surface pH & $\begin{array}{c}\text { Residence time } \\
(\mathrm{min})\end{array}$ \\
\hline $\mathrm{C}$ & $64.67 \pm 3.97$ & $256.25 \pm 12.26$ & $6.58 \pm 0.01$ & $25.58 \pm 5.31$ \\
$\mathrm{C}-\mathrm{T}$ & $75.89 \pm 8.80$ & $344.36 \pm 17.75$ & $4.74 \pm 0.01$ & $82.33 \pm 4.87$ \\
10CHDAC & $95.11 \pm 8.11$ & $383.12 \pm 1.96$ & $7.66 \pm 0.07$ & $69.44 \pm 2.63$ \\
10CHDAC-T & $107.97 \pm 6.11$ & $436.39 \pm 19.33$ & $5.32 \pm 0.07$ & $96.46 \pm 3.60$ \\
20CHDAC & $130.60 \pm 5.21$ & $522.53 \pm 12.29$ & $7.94 \pm 0.04$ & $75.03 \pm 11.43$ \\
20CHDAC-T & $140.80 \pm 6.16$ & $662.09 \pm 26.27$ & $6.43 \pm 0.07$ & $84.95 \pm 12.77$ \\
10CHDG & $96.43 \pm 10.68$ & $372.21 \pm 4.23$ & $7.46 \pm 0.07$ & $58.83 \pm 13.29$ \\
10CHDG-T & $110.01 \pm 5.12$ & $474.32 \pm 22.56$ & $4.86 \pm 0.11$ & $7.76 \pm 0.10$ \\
20CHDG & $131.42 \pm 8.29$ & $522.11 \pm 15.69$ & $5.11 \pm 0.05$ & $60.01 \pm 11.82$ \\
20CHDG-T & $144.96 \pm 10.08$ & $679.53 \pm 25.34$ & & $97.36 \pm 9.54$ \\
\hline
\end{tabular}

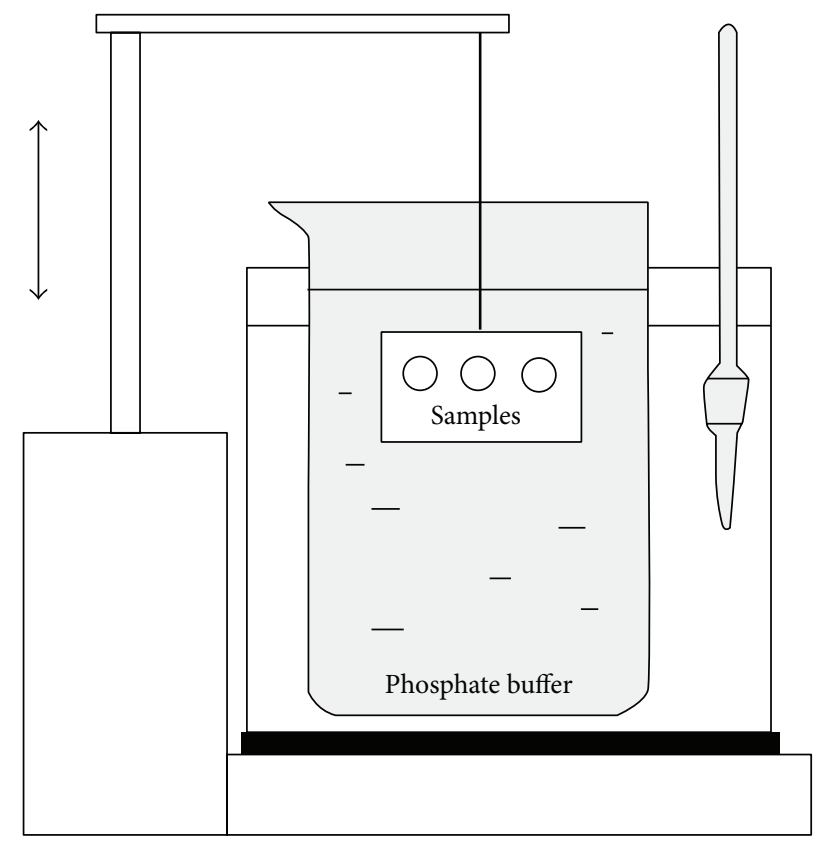

FIGURE 1: Modified disintegration apparatus for determination of in vitro residence time.

Texture Analyzer (Brookfield, USA) equipped with a 4.5$\mathrm{kg}$ load cell was used for tensile testing of the prepared MOFs. Film samples $(10 \times 40 \mathrm{~mm})$ were held between two clamps of probe TA-DGA positioned at a distance of $2 \mathrm{~cm}$. The lower clamp was held stationary, and the upper clamp moved at a rate of $0.5 \mathrm{~mm} / \mathrm{s}$ to pull apart the strips of mucoadhesive layers until the strip broke. The strength and work done during this process and the deformation of the film (elongation) at the moment of tearing were measured. This measurement was repeated three times per sample.

The texture analyzer with a TA39 cylindrical probe $(2 \mathrm{~mm}$ diameter) was used for a puncture test. The strength needed to puncture square samples $(25 \times 25 \mathrm{~mm})$ fixed in the JIG TA$\mathrm{CJ}$, the work done during this process, and the deformation of the film at the moment of penetration were measured. The layer with sedimented drug or textile material was oriented downwards, and the mucoadhesive layer faced upward. This measurement was repeated three times per sample.

Because the films were of different thicknesses and were prepared using different methods (solvent casting or impregnation), values measured by the texture analyzer were recalculated for the film thickness $100 \mu \mathrm{m}$ for better comparison (Table 3).

As well as in the case of solid samples, the morphology of prepared MOFs was characterized by SEM Philips XL 30. SEM images were obtained using back-scatter detector (BSE) and accelerating voltage $20 \mathrm{kV}$.

2.7. Multivariate Data Analysis. Methods of principal component analysis (PCA) were used for descriptive evaluation of the experimental data. Prior to modeling, the variables were adjusted by autoscaling, that is, mean centering and scaling by standard deviation. The influence of formulation variables (Table 1) on the parameters of mechanical resistance, in vitro residence time, and surface $\mathrm{pH}$ was subsequently evaluated using multiple linear regression (MLR) with use of analysis of variance (ANOVA). MLR models was assessed on the basis of characteristics such as $R$-square regression (which describes each model's explained variability), $R$-square of prediction (which expresses the model's predictive ability), and coefficient of variation (CV\%; the average modeling error expressed as a percentage of the mean). Statistical evaluations were conducted using the program Unscrambler X (v. 10.3, Camo Software, NOR).

\subsection{Antimicrobial Tests}

2.8.1. Organovermiculites. The minimum inhibitory concentration (MIC) of the prepared organovermiculite samples was defined as the lowest concentration that completely inhibited bacterial growth. Dilution and cultivation were performed on 96-well microtitration plates. The highest applied concentration of active substance was $10 \%(\mathrm{w} / \mathrm{v})$. The dispersions were further diluted using a threefold dilution method in glucose stock in such a manner that the second through the seventh rows of wells contained sample dispersed in concentrations of $3.33 \%, 1.11 \%, 0.37 \%, 0.12 \%, 0.04 \%$, and $0.01 \%$. The eighth row 
of wells contained pure glucose stock as a control test. Glucose suspensions of S. aureus CCM $3953\left(1.1 \times 10^{9} \mathrm{CFU} / \mathrm{mL}\right)$ and $C$. albicans ATC90028 $\left(1.1 \times 10^{9} \mathrm{CFU} / \mathrm{mL}\right), 1 \mu \mathrm{L}$ each, provided by the Czech collection of microorganisms were applied to the wells. One microliter of each microorganism suspension was transferred (after 30, 60, 90, 120, 180, 240, and $300 \mathrm{~min}$, and then at 24-h intervals for 5 days) from each well into $100 \mu \mathrm{L}$ of fresh glucose stock and incubated at $37^{\circ} \mathrm{C}$ for 24 and $48 \mathrm{~h}$. Antibacterial activity was evaluated by turbidity, which indicates bacterial growth [60]; that is, lower turbidity correlates with greater growth inhibition.

2.8.2. Mucoadhesive Oral Films. The suspension of S. aureus $\left(50 \mu \mathrm{L}\right.$, density $\left.10^{8} / \mathrm{mL}\right)$ and/or C. albicans $(50 \mu \mathrm{L}$, density $10^{8} / \mathrm{mL}$ ) was applied to MOFs with a surface area of $1.77 \mathrm{~cm}^{2}$ (circular sample, $15 \mathrm{~mm}$ diameter). Both strains were incubated under the same conditions (dark, $37^{\circ} \mathrm{C}$, Petri dish). Subsequently, MOFs were investigated by direct imprinting on solid culture medium (blood agar for S. aureus; Sabouraud agar for C. albicans) at time periods of 30,60, 120, 180, 240, and $300 \mathrm{~min}$ and then at $24,48,72$, and $96 \mathrm{~h}$. After incubation (24 and $48 \mathrm{~h}$ ), the growth of bacteria and yeast strains was observed and expressed as the number of colony forming units (CFU) on the surface of the imprint [60].

\section{Results and Discussion}

3.1. Characterization of Vermiculite Samples. The XRD pattern of the natural $\mathrm{Mg}^{2+}$ Ver showed the sequence of the basal reflections (Figure 2). The value $d(002)=1.430 \mathrm{~nm}$ confirmed the presence of two layers of water molecules around the exchangeable cations in the interlayer space [61, 62]. Treatment of $\mathrm{Mg}^{2+}$ Ver with CA and/or CG at concentrations of $0.5 \times$ CEC led to intercalation, which expanded the space between the layers and resulted in the appearance of a new reflection, designated on the XRD patterns as $d=2.197 \mathrm{~nm}$ $\left(\mathrm{Mg}^{2+}\right.$ Ver_CA $)$ and $d=2.157 \mathrm{~nm}\left(\mathrm{Mg}^{2+}\right.$ Ver_CG). Another new reflection in the XRD patterns of both organovermiculites of approximately $1 \mathrm{~nm}$ corresponded to the dehydrated vermiculite phase $[62,63]$.

The IR spectrum of $\mathrm{Mg}^{2+}$ Ver (Figure 3 ) shows a band at $3674 \mathrm{~cm}^{-1}$ in the $\mathrm{OH}$ stretching region attributed to the $\mathrm{Mg}_{3} \mathrm{OH}$ unit; and absorption at $668 \mathrm{~cm}^{-1}$ belonging to the $\mathrm{OH}$ bending vibration. These bands suggest that vermiculite has a trioctahedral character [64]. Absorption at $3566 \mathrm{~cm}^{-1}$ in the $\mathrm{OH}$ stretching region belongs to the $\mathrm{Fe}_{2} \mathrm{OH}$ unit. The presence of this band indicates that although vermiculite is nominally trioctahedral, some of the $\mathrm{OH}$ groups are associated with vacancies and are in a locally dioctahedral environment [64]. The absorption observed at $3368 \mathrm{~cm}^{-1}$ corresponds to the $\mathrm{OH}$ stretching vibration of adsorbed water, and the adsorption observed at $1653 \mathrm{~cm}^{-1}$ corresponds to the $\mathrm{OH}$ bending vibration of adsorbed water. Finally, an intensive band at $1001 \mathrm{~cm}^{-1}$ was assigned to the $\mathrm{Si}-\mathrm{O}$ stretching vibration together with the $\mathrm{Si}-\mathrm{O}$ bending vibration at $446 \mathrm{~cm}^{-1}$ [65]. The IR spectra of organovermiculites $\mathrm{Mg}^{2+}$ Ver_CA and $\mathrm{Mg}^{2+}$ Ver_CG (Figure 3 ) showed new bands

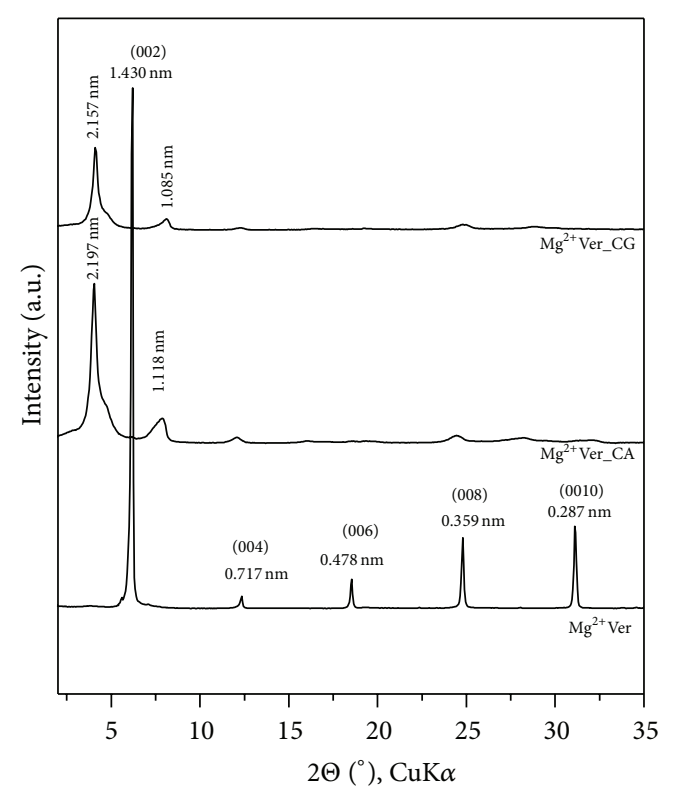

FIGURE 2: XRD patterns of natural $\mathrm{Mg}^{2+}$ Ver and the organovermiculite samples $\mathrm{Mg}^{2+}$ Ver_CA and $\mathrm{Mg}^{2+}$ Ver_CG.

at 3350 and $3338 \mathrm{~cm}^{-1}$, which correspond to the asymmetric $\mathrm{NH}$ stretching bands, and those at 3220 and $3214 \mathrm{~cm}^{-1}$ correspond to the symmetric NH stretching bands of CA and CG, respectively [66, 67]. Bands at 2935, 2934 and $2859,2858 \mathrm{~cm}^{-1}$ are assigned to asymmetric and symmetric $\mathrm{C}-\mathrm{H}$ stretching bands of CA and CG, respectively [66, 67]. The bands found in the $1580-1490 \mathrm{~cm}^{-1}$ region in both organovermiculite spectra originate in the $\mathrm{NH}$ bending vibration of secondary amine and imine groups $[66,67]$. Because the $\mathrm{C}=\mathrm{N}$ stretching vibration of the imine group appears near $1645 \mathrm{~cm}^{-1}$, it is difficult to distinguish because this band overlaps the water bending vibration of $\mathrm{Mg}^{2+}$ Ver. The absorption at $1418 \mathrm{~cm}^{-1}$ belongs to the $\mathrm{C}=\mathrm{C}$ stretching vibrations of the aromatic ring and the C-H out-of-plane deformation vibrations of the 1,4disubstituted aromatic ring near $825 \mathrm{~cm}^{-1}$.

The particle size (PS) parameters were measured by the laser diffraction method in liquid mode. The parameters obtained from measurements are median diameter $\left(d_{50}\right)$ and the volume-weighted mean diameter $\left(d_{43}\right)$. Table 2 shows growth of these parameters after treatment of natural $\mathrm{Mg}^{2+}$ Ver with antimicrobial drugs.

SEM images of natural clay $\mathrm{Mg}^{2+} \mathrm{Ver}$ and organovermiculite samples are shown in Figure 4, magnified 120x and $1500 \mathrm{x}$. The particle size is not obvious from the images in $120 \mathrm{x}$ magnification (Figures 4(a), 4(c), and 4(d)). For this reason, particle size distribution analysis was preferred. On the other hand from images of organovermiculite samples in 1500x magnification (Figures 4(d) and 4(f)) the enlargement of clay layers could be seen due to the intercalation of antimicrobial drugs into natural clay $\mathrm{Mg}^{2+}$ Ver structure (Figure 4(b)). These results correspond with the results form XRD analysis, in which antimicrobial drugs were intercalated into interlayer space of clay. 


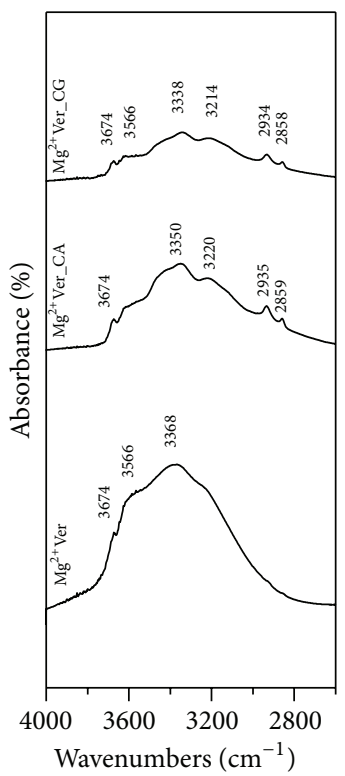

(a)

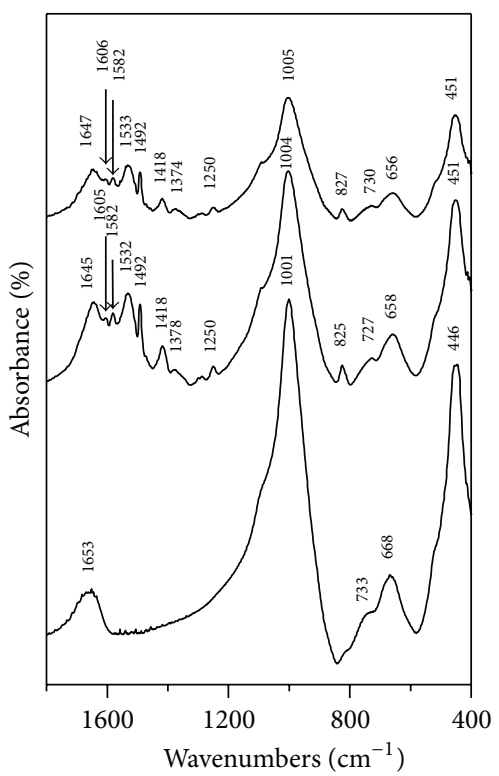

(b)

Figure 3: IR spectra of natural $\mathrm{Mg}^{2+}$ Ver and the organoclay samples $\mathrm{Mg}^{2+}$ Ver_CA and $\mathrm{Mg}^{2+}$ Ver_CG.

3.2. Physicomechanical, Chemical, and Morphological Properties of MOFs. Overall, the weight of the prepared films ranged from values of $64.67 \pm 3.97 \mathrm{mg}$ (sample C) to $144.96 \pm 10.08 \mathrm{mg}$ (sample 20CHDG-T) (Table 3), which are not problematic for oral application. In general, MOFs with nonwoven textile exhibited greater weights than samples prepared by solvent casting method. The addition of an organoclay composite to the samples also increased their weight. Generally, films without active agent showed the lowest weight (C: $64.67 \pm$ $3.97 \mathrm{mg}$; CT: $75.89 \pm 8.80 \mathrm{mg}$ ) (Table 3). In contrast, films with $20 \mathrm{mg}$ of intercalated chlorhexidine diacetate and chlorhexidine digluconate weighed the most (20CHDAC: $130.60 \pm$ $5.21 \mathrm{mg}$; 20CHDAC-T: $140.80 \pm 6.16 \mathrm{mg}$; 20CHDG: $131.42 \pm 8$, 29 mg; 20CHDG-T: $144.96 \pm 10.08$ ) (Table 3). Films containing chlorhexidine digluconate composite were of slightly greater weights than films containing chlorhexidine diacetate, although they contained the same amount of the active agent and textile material (Table 3).

The thickness of the prepared MOFs ranged from 256.25 \pm $12.26 \mu \mathrm{m}$ (C) to $679.53 \pm 25.34 \mu \mathrm{m}$ (20CHDG-T) (Table 3). MOFs without drugs were the thinnest (C: $256.25 \pm 12.26 \mu \mathrm{m}$; CT: $344.36 \pm 17.75 \mu \mathrm{m}$ ) (Table 3). Films with $20 \mathrm{mg}$ of chlorhexidine diacetate or chlorhexidine digluconate had the greatest average thickness (20CHDAC: $522.53 \pm 12.29 \mu \mathrm{m}$; 20CHDAC-T: $662.09 \pm 26.27 \mu \mathrm{m} ; 20 \mathrm{CHDG}: 522.11 \pm$ $15.69 \mu \mathrm{m} ; 20 \mathrm{CHDG}-\mathrm{T}: 679.53 \pm 25.34 \mu \mathrm{m}$ ) (Table 3). With the same amount of active agent and same textile material present, thicker MOFs were produced from organoclay containing chlorhexidine digluconate than chlorhexidine diacetate (Table 3). Films without textile samples containing $20 \mathrm{mg}$ drug were of almost the same thickness (20CHDAC: $522.53 \pm 12.29 \mu \mathrm{m} ; 20 \mathrm{CHDG}: 522.11 \pm 15.69 \mu \mathrm{m})$, but films with $10 \mathrm{mg}$ chlorhexidine diacetate were thicker than films with $10 \mathrm{mg}$ chlorhexidine digluconate (10CHDAC: $383.12 \pm$ $1.96 \mu \mathrm{m}$; 10CHDG: $372.21 \pm 4.23 \mu \mathrm{m})$. The optimal thickness of buccal film with adequate mechanical durability and mucoadhesive properties and without interference in the oral cavity ranged from 50 to $1000 \mu \mathrm{m}$; all of the MOF sample films were within this range $[68,69]$.

$\mathrm{pH}$ value of the mucoadhesive films is also one of the important factors of their quality. Normal saliva $\mathrm{pH}$ is between 5.6 and 7.0. If the $\mathrm{pH}$ of the applied mucoadhesive dosage formulation is too acidic or too alkaline, it could cause local irritation in the oral cavity. Irritation of the buccal mucosa may lead to increased salivation, resulting in excessive hydration of the mucoadhesive films, faster dissolution of the film-forming polymers, and faster erosion of the mucoadhesive bonds. The result is usually an insufficient residence time on the buccal mucosa $[16,41,70]$.

Films with incorporated nonwoven textile from an acid formulation of CMC have been assumed to exhibit lower $\mathrm{pH}$ values (Table 3 ). This observation results from the $\mathrm{pH}$ of the aqueous extract of the textile material, which ranges from 3.5 to 5.0 [71]. The addition and increasing amount of organoclays with both forms of chlorhexidine to the formulation increased the $\mathrm{pH}$ of the samples (Table 3). This phenomenon might be explained by the basic nature of chlorhexidine [72]. It was also observed (Table 3) that films containing chlorhexidine diacetate exhibited higher $\mathrm{pH}$ values and films with chlorhexidine digluconate exhibited lower $\mathrm{pH}$ values (while maintaining the same amount of active ingredient and the same representation of nonwoven textile). This might be explained by the $\mathrm{p} K_{\mathrm{a}}$ of the acids forming the chlorhexidine salts. Lower $\mathrm{p} K_{\mathrm{a}}$ value implies that the given acid is of a stronger nature. The $\mathrm{p} K_{\mathrm{a}}$ of gluconic acid is 3.70, while the $\mathrm{p} K_{\mathrm{a}}$ of acetic acid is 4.74 . Gluconic 


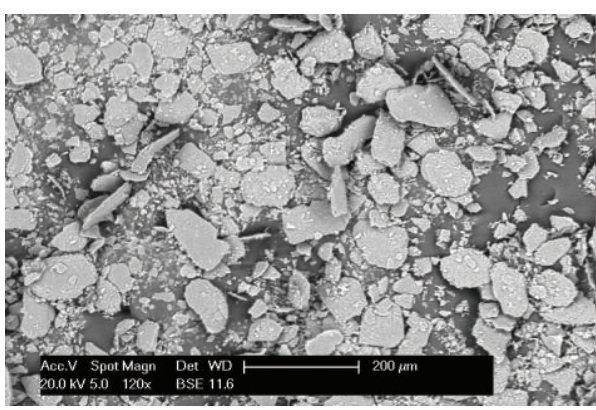

(a)

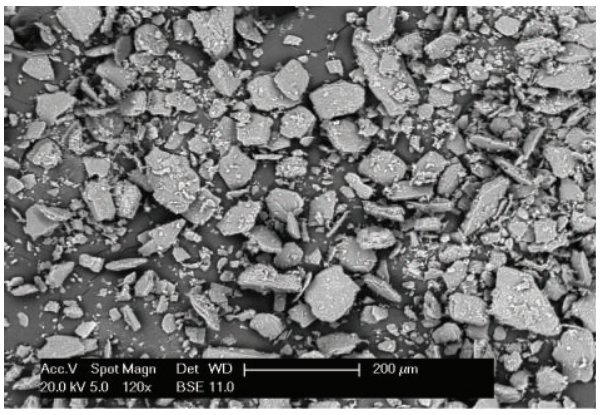

(c)

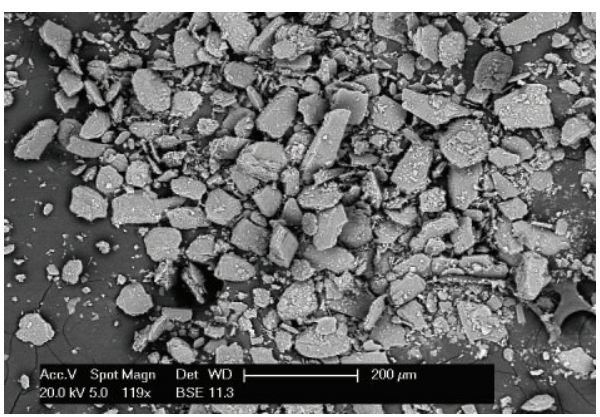

(e)

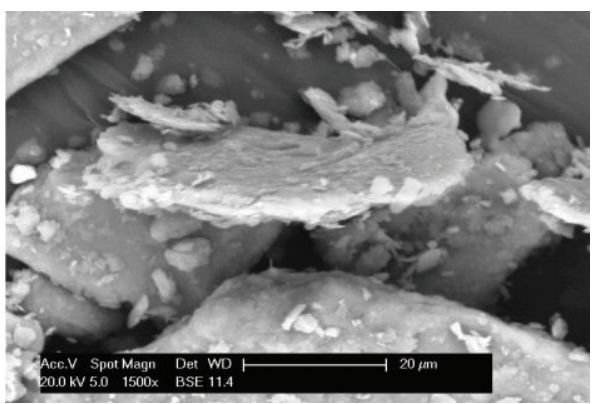

(b)

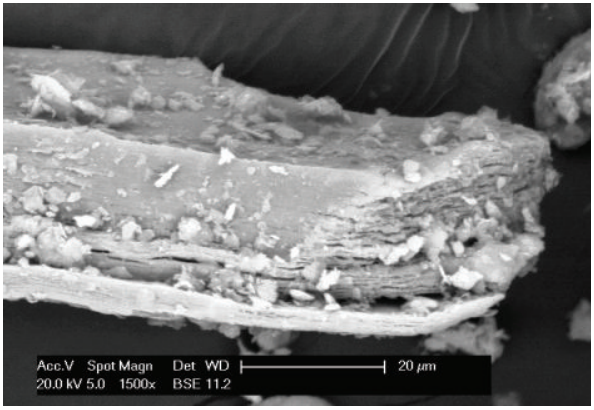

(d)

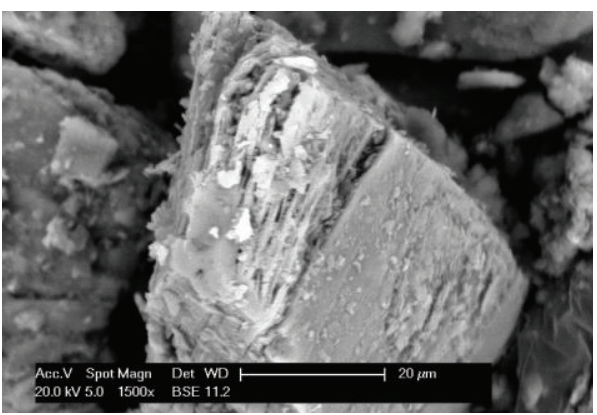

(f)

FIGURE 4: SEM photographs of parent clay and organoclay samples. (a) $\mathrm{Mg}^{2+} \operatorname{Ver}(120 \mathrm{x})$; (b) $\mathrm{Mg}^{2+} \operatorname{Ver}(1500 \mathrm{x})$; (c) $\mathrm{Mg}^{2+}$ Ver_CA (120x); (d) $\mathrm{Mg}^{2+}$ Ver_CA (1500x); (e) $\mathrm{Mg}^{2+} \operatorname{Ver} \_C G(120 \mathrm{x}) ;(\mathrm{f}) \mathrm{Mg}^{2+}$ Ver_CG (1500x).

acid is therefore the strongest of these two acids, and films containing chlorhexidine digluconate exhibited lower $\mathrm{pH}$ values.

The in vitro residence time was evaluated in order to determine the mucoadhesion ability of MOFs, as well as the influence of the presence of organoclay and nonwoven textile on this characteristic $[69,73]$. The presence of nonwoven textile and the addition of chlorhexidine organoclay composite each increased the in vitro residence time of the mucoadhesive film on the artificial mucosa (Table 3 ).

Films containing nonwoven textile from the acid form of carmellose remained on the artificial buccal mucosa longer than samples without the textile (from $25.58 \pm 5.31 \mathrm{~min}$ (CT sample) to $75.03 \pm 11.43 \mathrm{~min}$ (20CHDAC-T sample)). This observation might be explained by their greater mechanical strength and the strong ability of carmellose to bind to biological surfaces [18]. The effect of chlorhexidine organoclay might be explained by the substantivity phenomenon of chlorhexidine, which could be described as its ability to bind to buccal mucosal structures [74, 75].

The results of the MLR model for films with incorporated active substance $(R$-square $>0.70 ; R$-square prediction $>$ $0.50 ; \mathrm{CV} \%<13$, model $P<0.01)$ indicated that the nonwoven textile had a statistically significant effect on the in vitro residence time $(P<0.001)$. It was disabled to confirm the statistical significance of the addition of different type of chlorhexidine on the residence time of MOFs, because of high levels of noise in the measurements.

Texture analysis was employed to evaluate the mechanical properties of the prepared MOFs. Films were characterized in two different ways: tensile testing (tensile strength, tensile work, and elongation) and puncture testing (puncture strength, puncture work, and deformation). The results of these measurements are summarized in Table 4.

It was observed that the incorporation of the nonwoven textile into the structure of MOFs influenced the properties 
TABLE 4: Mechanical properties of prepared mucoadhesive oral films.

\begin{tabular}{|c|c|c|c|c|c|c|}
\hline \multirow[b]{2}{*}{ Sample } & \multicolumn{3}{|c|}{ Tensile testing } & \multicolumn{3}{|c|}{ Puncture testing } \\
\hline & $\begin{array}{l}\text { Tensile strength } \\
(\mathrm{N})\end{array}$ & $\begin{array}{c}\text { Tensile work } \\
(\mathrm{m} J)\end{array}$ & $\begin{array}{c}\text { Elongation } \\
(\mathrm{mm})\end{array}$ & $\begin{array}{c}\text { Puncture } \\
\text { strength }(\mathrm{N})\end{array}$ & $\begin{array}{l}\text { Puncture work } \\
(\mathrm{mJ})\end{array}$ & $\begin{array}{l}\text { Deformation } \\
(\mathrm{mm})\end{array}$ \\
\hline $\mathrm{C}$ & $24.31 \pm 0.60$ & $325.00 \pm 30.62$ & $28.27 \pm 3.49$ & $15.40 \pm 1.11$ & $29.02 \pm 2.90$ & $4.92 \pm 0.17$ \\
\hline $\mathrm{C}-\mathrm{T}$ & $33.79 \pm 0.57$ & $176.70 \pm 1.67$ & $5.30 \pm 0.05$ & $23.52 \pm 0.62$ & $28.64 \pm 1.15$ & $2.79 \pm 0.12$ \\
\hline 10CHDAC & $27.63 \pm 3.31$ & $317.71 \pm 39.35$ & $19.19 \pm 1.52$ & $15.29 \pm 0.96$ & $22.58 \pm 1.36$ & $3.60 \pm 0.04$ \\
\hline 10CHDAC-T & $40.14 \pm 1.42$ & $156.28 \pm 15.31$ & $4.66 \pm 0.04$ & $22.65 \pm 1.14$ & $28.44 \pm 1.58$ & $2.20 \pm 0.12$ \\
\hline 20CHDAC & $32.34 \pm 2.25$ & $332.64 \pm 34.28$ & $15.47 \pm 0.79$ & $14.34 \pm 0.64$ & $19.96 \pm 0.91$ & $2.72 \pm 0.04$ \\
\hline 20CHDAC-T & $42.39 \pm 1.23$ & $116.14 \pm 13.59$ & $3.20 \pm 0.02$ & $21.08 \pm 0.59$ & $33.42 \pm 0.65$ & $1.76 \pm 0.03$ \\
\hline 10CHDG & $24.40 \pm 1.61$ & $299.96 \pm 10.18$ & $21.39 \pm 0.37$ & $13.98 \pm 1.70$ & $22.35 \pm 3.20$ & $3.65 \pm 0.23$ \\
\hline 10CHDG-T & $38.09 \pm 0.37$ & $167.28 \pm 31.11$ & $4.80 \pm 0.23$ & $23.29 \pm 1.07$ & $28.84 \pm 2.55$ & $2.45 \pm 0.02$ \\
\hline 20CHDG & $21.98 \pm 2.72$ & $227.15 \pm 46.96$ & $14.65 \pm 2.27$ & $12.41 \pm 0.48$ & $18.88 \pm 1.22$ & $2.77 \pm 0.11$ \\
\hline 20CHDG-T & $38.06 \pm 1.44$ & $136.70 \pm 20.64$ & $3.97 \pm 0.51$ & $18.67 \pm 1.52$ & $28.76 \pm 1.42$ & $1.89 \pm 0.01$ \\
\hline
\end{tabular}

of prepared films. Films with incorporated nonwoven textile exhibited higher strength and less elongation than films without the textile (Table 4 ). The measured elongation values ranged from $14.65 \mathrm{~mm}$ (20CHDG) to $28.27 \mathrm{~mm}$ (C) for films without textile and from $3.20 \mathrm{~mm}$ (20CHDAC-T) to $5.30 \mathrm{~mm}$ (C-T) for films with textile (Table 4). The strength required to break the sample was $4.21 \pm 0.52 \mathrm{~N}$ (20CHDG) to $9.49 \pm 0.23 \mathrm{~N}$ (C) for films without textile and $5.60 \pm 0.21 \mathrm{~N}$ (20CHDGT) to $9.81 \pm 0.16 \mathrm{~N}(\mathrm{C}-\mathrm{T})$ for films prepared using the impregnation method (Table 4). The resulting tensile work was lower for samples without textile than for samples with textile (Table 4). The measured values of tensile strength and elongation indicated that the samples without the nonwoven textile were softer and more flexible, while the samples with textile were less flexible and possessed greater stiffness. Adding chlorhexidine organoclay reduced the elongation values (Table 4).

In samples without nonwoven textile, the deformation of films during puncture testing varied from $2.72 \mathrm{~mm}$ (20CHDAC) to $4.72 \mathrm{~mm}(\mathrm{C})$. In contrast, films with incorporated nonwoven textile exhibited deformation in the range of $1.76 \mathrm{~mm}$ (20CHDAC-T) to $2.79 \mathrm{~mm}$ (C-T) (Table 3). The strength required to puncture the films without nonwoven textile was $2.38 \pm 0.09 \mathrm{~N}$ (20CHDG) to $6.01 \pm 0.43 \mathrm{~N}$ (C), versus $2.75 \pm 0.22 \mathrm{~N}$ (20CHDG-T) to $6.83 \pm 0.18 \mathrm{~N}$ (C-T) for films prepared by impregnation (Table 4). Samples without nonwoven textile exhibited greater degrees of deformation, and less strength was needed to puncture them (Table 4). The resulting work required to puncture the sample, which is related to both the strength needed and the deformation rate, was generally less for samples without textile than for samples with nonwoven textile in their structure (Table 4). Films without textile were more flexible and exhibited greater softness. Conversely, films with nonwoven textile deformed less under pressure, and greater strength and more work were generally required to puncture them. This observation indicated the reduced flexibility and greater hardness/durability of these samples. The addition of chlorhexidine organoclay reduced the strength needed to puncture the samples, as well as their deformation. This effect became stronger as the amount of active material in the MOFs increased (Table 4).

The morphology of the prepared MOFs was evaluated by SEM (all the presented photographs are made in the $120 \mathrm{x}$ magnification). From the SEM images of pure carmellose film, C (Figure 5(a)), and MOF with antimicrobial nanocomposite, 20CHDAC (Figure 5(b)), it is evident that organoclay sample was anchored on the mucoadhesive polymer surface (Figure 5(b) upper layer is organoclay $\mathrm{Mg}^{2+}$ Ver_CA and bottom layer is carmellose). Figure 5(c) shows carmellose film with nonwoven textile (C-T), where nonwoven textile creates a rough surface (upper side of film). Image Figure 5(d) belongs to carmellose film with nonwoven textile and anchored antimicrobial nanocomposite (20CHDAC-T). In this case, it is evident that layer of organoclay $\mathrm{Mg}^{2+}$ Ver_CA was anchored on carmellose film.

The chosen properties of films prepared with active substances were also evaluated using PCA and MLR. The objects were distributed into four groups in the space of the first two components based on the presence of nonwoven textile and concentration of active substance (Figure 6(a)). Principal components are explained by variables shown in the PCA correlation loadings plot (Figure 6(b)), where variables near each other are strongly correlated.

MLR modeling was performed with the aim of obtaining models that were able to determine the effects of formulation variables from films prepared with the active substance on different mechanical properties $(R$-square $>0.80$; $R$-square of prediction $>0.65$; CV\% $<20$; models $P<0.001$ ). MLR confirmed that the presence of nonwoven textile had significant negative effects on elongation, deformation, and tensile work $(P<0.001$ for all $)$ and significant positive effects on tensile strength, puncture work, and puncture strength $(P<0.01$ for all). This trend is also apparent in the PCA correlation loadings plot (Figure 6(b)), in which the described variables are correlated in the opposite PC-2 space based on presence of the textile (Figure 6(a)). In this experiment, nonwoven textile increased the strength of films prepared from a $4 \%$ dispersion of $\mathrm{NaCMC}$; that result was in 


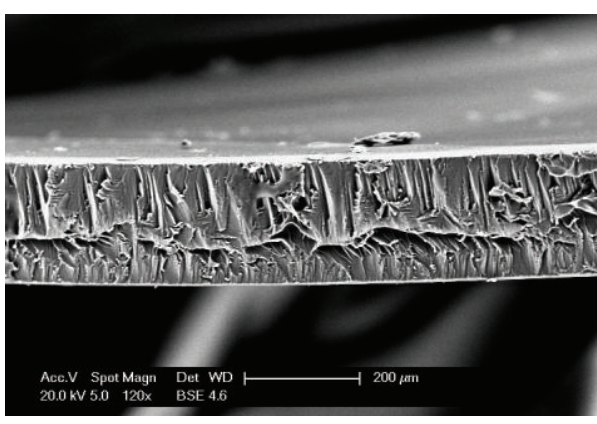

(a)

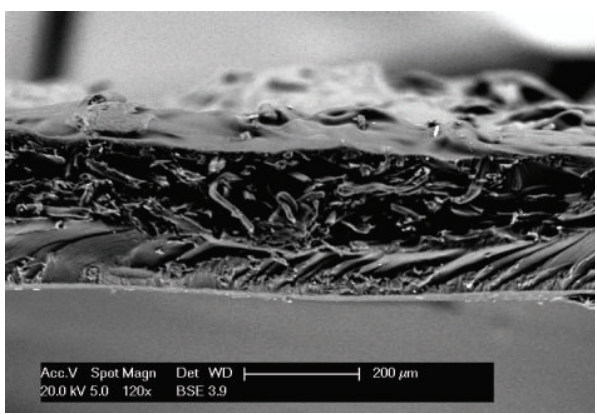

(c)

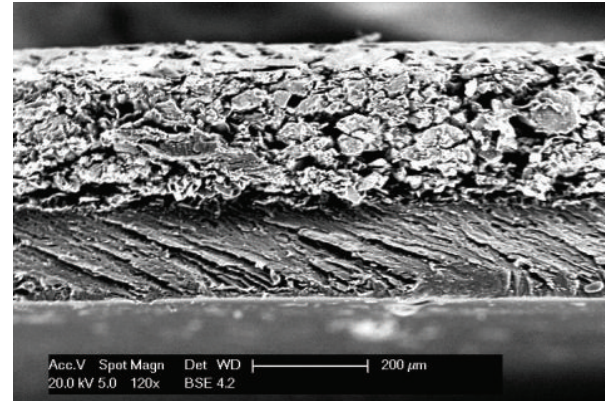

(b)

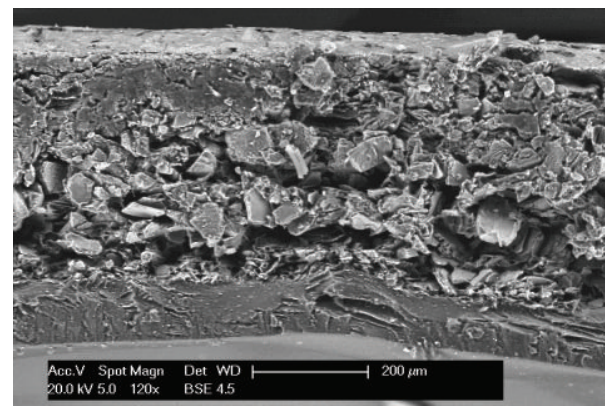

(d)

Figure 5: SEM photographs (120x) of MOFs structure. Samples: (a) C; (b) 20CHDAC; (c) C-T; (d) 20CHDAC-T.

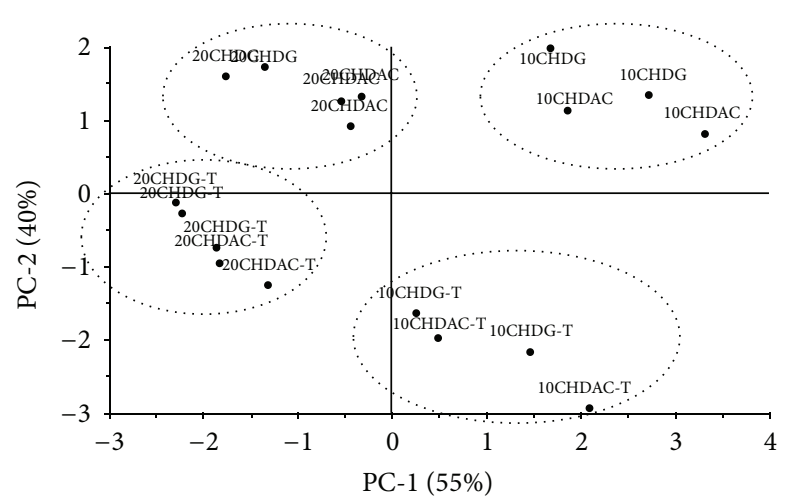

(a)

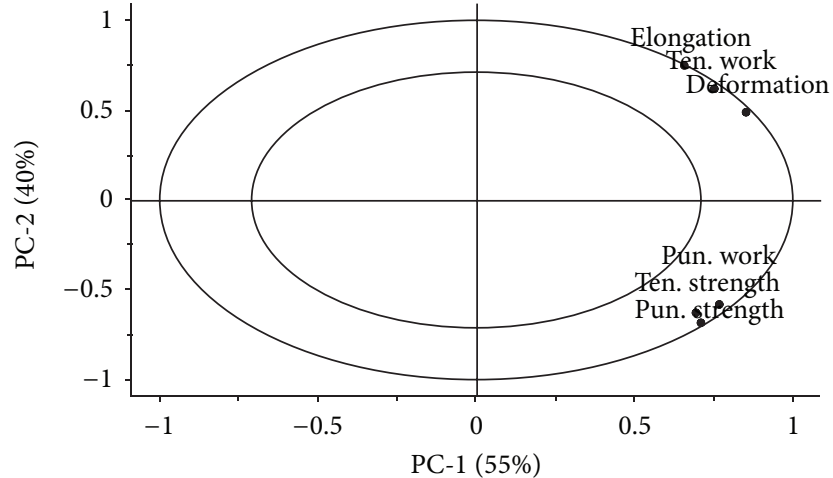

(b)

FIGURE 6: Principal component analysis. (a) Scores plot. (b) Correlation loadings plot.

contrast to the previous experiment, in which the addition of a nonwoven textile reduced the strength of films prepared from a $2 \%$ dispersion of NaCMC [21]. Furthermore, the concentration of active substance had a significant negative effect on all observed textural variables $(P<0.001)$, which could be illustrated by their correlation in the right part of the PC-1 in the correlation loadings plot (Figure 3(b)) based on the concentration of active substance (Figure 6(a)).

\subsection{Antimicrobial Tests}

3.3.1. Organovermiculites. Antimicrobial tests were performed against the bacterial strain S. aureus (STAU) and the yeast $C$. albicans (CAAL). The activity of prepared organoclays was observed at various time periods.
The MIC values of $\mathrm{Mg}^{2+}$ Ver_CA and $\mathrm{Mg}^{2+}$ Ver_CG (Table 5) indicated that both samples were effective against STAU after $\geq 24 \mathrm{~h}$. The MIC values for this microorganism were determined for both $\mathrm{Mg}^{2+}$ Ver_CA and $\mathrm{Mg}^{2+}$ Ver_CG samples at a concentration of $0.01 \%(w / v)$. Slightly worse results were obtained with both organovermiculite samples against CAAL after $\geq 24 \mathrm{~h}$ (MIC was $0.37 \%$ for $\mathrm{Mg}^{2+}$ Ver_CA, and $1.11 \%$ for $\mathrm{Mg}^{2+}$ Ver_CG). However, these samples gave better results against yeast in short time intervals (from $120 \mathrm{~min}$ ), in contrast to STAU (Table 5).

3.3.2. Mucoadhesive Oral Films. Antimicrobial tests against the bacterial strain $S$. aureus and the yeast $C$. albicans were performed with mucoadhesive films by direct imprinting on 


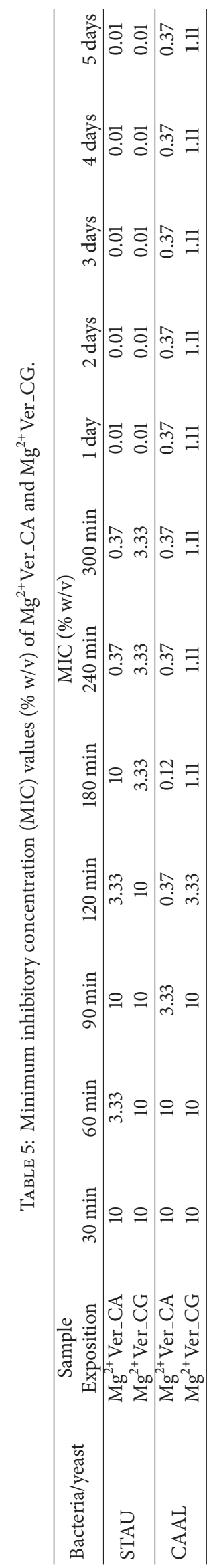


TABLE 6: Antimicrobial properties of mucoadhesive oral films against Staphylococcus aureus.

\begin{tabular}{|c|c|c|c|c|c|c|c|c|c|c|c|}
\hline \multirow{2}{*}{$\begin{array}{l}\text { Sample } \\
\text { Exposition }\end{array}$} & \multicolumn{11}{|c|}{$\mathrm{CFU}$} \\
\hline & $30 \mathrm{~min}$ & $60 \mathrm{~min}$ & $90 \mathrm{~min}$ & $120 \mathrm{~min}$ & $180 \mathrm{~min}$ & $240 \mathrm{~min}$ & $300 \mathrm{~min}$ & 1 day & 2 days & 3 days & 4 days \\
\hline 10CHDAC & $\mathrm{CN}$ & $\mathrm{CN}$ & $\mathrm{CN}$ & $\mathrm{CN}$ & $\mathrm{CN}$ & $\mathrm{CN}$ & $\mathrm{CN}$ & 55 & 0 & 0 & 0 \\
\hline 10CHDAC-T & $\mathrm{CN}$ & $\mathbf{0}$ & 0 & 0 & 0 & 0 & 0 & 0 & 0 & 0 & 0 \\
\hline 20CHDAC & $\mathrm{CN}$ & $\mathrm{CN}$ & $\mathrm{CN}$ & $\mathrm{CN}$ & $\mathrm{CN}$ & $\mathrm{CN}$ & $\mathrm{CN}$ & $\mathbf{0}$ & 0 & 0 & 0 \\
\hline 20CHDAC-T & $\mathrm{CN}$ & $\mathbf{0}$ & 0 & 0 & 0 & 0 & 0 & 0 & 0 & 0 & 0 \\
\hline 10CHDG & $\mathrm{CN}$ & $\mathrm{CN}$ & $\mathrm{CN}$ & $\mathrm{CN}$ & $\mathrm{CN}$ & $\mathrm{CN}$ & $\mathrm{CN}$ & $\mathrm{CN}$ & $\mathbf{0}$ & 0 & 0 \\
\hline 10CHDG-T & $\mathbf{0}$ & 0 & 0 & 0 & 0 & 0 & 0 & 0 & 0 & 0 & 0 \\
\hline 20CHDG & $\mathrm{CN}$ & $\mathrm{CN}$ & $\mathrm{CN}$ & $\mathrm{CN}$ & $\mathrm{CN}$ & $\mathrm{CN}$ & $\mathrm{CN}$ & $\mathbf{0}$ & 0 & 0 & 0 \\
\hline 20CHDG-T & $\mathrm{CN}$ & 7 & 0 & 0 & 0 & 0 & 0 & 0 & 0 & 0 & 0 \\
\hline $\mathrm{C}$ & $\mathrm{CN}$ & $\mathrm{CN}$ & $\mathrm{CN}$ & $\mathrm{CN}$ & $\mathrm{CN}$ & $\mathrm{CN}$ & $\mathrm{CN}$ & $\mathrm{CN}$ & $\mathrm{CN}$ & $\mathrm{CN}$ & $\mathrm{CN}$ \\
\hline $\mathrm{C}-\mathrm{T}$ & $\mathrm{CN}$ & $\mathrm{CN}$ & $\mathrm{CN}$ & $\mathrm{CN}$ & $\mathrm{CN}$ & $\mathrm{CN}$ & $\mathrm{CN}$ & $\mathrm{CN}$ & $\mathrm{CN}$ & $\mathrm{CN}$ & $\mathrm{CN}$ \\
\hline Growth on glass & $\mathrm{CN}$ & $\mathrm{CN}$ & $\mathrm{CN}$ & $\mathrm{CN}$ & $\mathrm{CN}$ & $\mathrm{CN}$ & $\mathrm{CN}$ & $\mathrm{CN}$ & $\mathrm{CN}$ & $\mathrm{CN}$ & $\mathrm{CN}$ \\
\hline Growth on blood agar & $\mathrm{CN}$ & $\mathrm{CN}$ & $\mathrm{CN}$ & $\mathrm{CN}$ & $\mathrm{CN}$ & $\mathrm{CN}$ & $\mathrm{CN}$ & $\mathrm{CN}$ & $\mathrm{CN}$ & $\mathrm{CN}$ & $\mathrm{CN}$ \\
\hline
\end{tabular}

$\mathrm{CN}$ (countless number: $>300 \mathrm{CFU}$ on the plate).

The initial time periods, in which microorganism growth was completely inhibited, are written in bold for each sample.

TABLE 7: Antimicrobial properties of mucoadhesive oral films against Candida albicans.

\begin{tabular}{|c|c|c|c|c|c|c|c|c|c|c|c|}
\hline \multirow{2}{*}{$\begin{array}{l}\text { Sample } \\
\text { Exposition }\end{array}$} & \multicolumn{11}{|c|}{$\mathrm{CFU}$} \\
\hline & $30 \mathrm{~min}$ & $60 \mathrm{~min}$ & $90 \mathrm{~min}$ & $120 \mathrm{~min}$ & $180 \mathrm{~min}$ & $240 \mathrm{~min}$ & $300 \mathrm{~min}$ & 1 day & 2 days & 3 days & 4 days \\
\hline 10CHDAC & $\mathrm{CN}$ & $\mathrm{CN}$ & $\mathrm{CN}$ & $\mathrm{CN}$ & 14 & 11 & 10 & 11 & 0 & 0 & 0 \\
\hline 10CHDAC-T & $\mathrm{CN}$ & $\mathrm{CN}$ & $\mathrm{CN}$ & $\mathrm{CN}$ & 4 & 3 & $\mathbf{0}$ & 0 & 0 & 0 & 0 \\
\hline 20CHDAC & $\mathrm{CN}$ & $\mathrm{CN}$ & $\mathrm{CN}$ & $\mathrm{CN}$ & $\mathrm{CN}$ & $\mathrm{CN}$ & 26 & 29 & 0 & 0 & 0 \\
\hline 20CHDAC-T & 3 & 1 & $\mathbf{0}$ & 6 & 3 & 2 & 5 & 0 & 0 & 0 & 0 \\
\hline 10CHDG & $\mathrm{CN}$ & $\mathrm{CN}$ & $\mathrm{CN}$ & $\mathrm{CN}$ & $\mathrm{CN}$ & $\mathrm{CN}$ & $\mathrm{CN}$ & $\mathrm{CN}$ & 23 & $\mathbf{0}$ & 0 \\
\hline 10CHDG-T & $\mathrm{CN}$ & $\mathrm{CN}$ & $\mathrm{CN}$ & $\mathrm{CN}$ & $\mathrm{CN}$ & $\mathrm{CN}$ & $\mathrm{CN}$ & $\mathrm{CN}$ & 10 & $\mathbf{0}$ & 0 \\
\hline $20 \mathrm{CHDG}$ & $\mathrm{CN}$ & $\mathrm{CN}$ & $\mathrm{CN}$ & $\mathrm{CN}$ & $\mathrm{CN}$ & $\mathrm{CN}$ & $\mathrm{CN}$ & 100 & 0 & 0 & 0 \\
\hline 20CHDG-T & $\mathrm{CN}$ & $\mathrm{CN}$ & $\mathrm{CN}$ & $\mathrm{CN}$ & $\mathrm{CN}$ & $\mathrm{CN}$ & 15 & 13 & 8 & $\mathbf{0}$ & 0 \\
\hline $\mathrm{C}$ & $\mathrm{CN}$ & $\mathrm{CN}$ & $\mathrm{CN}$ & $\mathrm{CN}$ & $\mathrm{CN}$ & $\mathrm{CN}$ & $\mathrm{CN}$ & $\mathrm{CN}$ & $\mathrm{CN}$ & $\mathrm{CN}$ & $\mathrm{CN}$ \\
\hline $\mathrm{C}-\mathrm{T}$ & $\mathrm{CN}$ & $\mathrm{CN}$ & $\mathrm{CN}$ & $\mathrm{CN}$ & $\mathrm{CN}$ & $\mathrm{CN}$ & $\mathrm{CN}$ & $\mathrm{CN}$ & $\mathrm{CN}$ & $\mathrm{CN}$ & $\mathrm{CN}$ \\
\hline growth on glass & $\mathrm{CN}$ & $\mathrm{CN}$ & $\mathrm{CN}$ & $\mathrm{CN}$ & $\mathrm{CN}$ & $\mathrm{CN}$ & $\mathrm{CN}$ & $\mathrm{CN}$ & $\mathrm{CN}$ & $\mathrm{CN}$ & $\mathrm{CN}$ \\
\hline growth on blood agar & $\mathrm{CN}$ & $\mathrm{CN}$ & $\mathrm{CN}$ & $\mathrm{CN}$ & $\mathrm{CN}$ & $\mathrm{CN}$ & $\mathrm{CN}$ & $\mathrm{CN}$ & $\mathrm{CN}$ & $\mathrm{CN}$ & $\mathrm{CN}$ \\
\hline
\end{tabular}

$\mathrm{CN}$ (countless number: $>300 \mathrm{CFU}$ on the plate).

The initial time periods, in which microorganism growth was completely inhibited, are written in bold for each sample.

a solid culture medium at various time periods. Tables 6 and 7 depict the colony forming units (CFU) of prepared mucoadhesive films and control samples $\mathrm{C}$ and C-M. From all of the prepared MOFs, samples 10CHDAC-T, 20CHDAC-T, 10CHDG-T, and 20CHDG-T were the most effective against STAU (complete inhibition of STAU growth in maximum $1.5 \mathrm{~h}$ ) (Table 6). The least effective samples against STAU were 10CHDAC and 10CHDG, which inhibited growth after $>48 \mathrm{~h}$ (Table 6). The most effective MOFs against CAAL were 10CHDAC-T and 20CHDAC-T (Table 7). These samples were also able to inhibit yeast growth after $>24 \mathrm{~h}$. It could be concluded that all of the prepared samples exhibited good effectiveness regarding STAU growth inhibition and that samples with nonwoven carmellose textile incorporated into their structure exhibited better results. This might be because of the acidic condition of the nonwoven textile, which was also observed with respect to the surface $\mathrm{pH}$ of prepared MOFs (Table 3). The effectiveness of MOFs against
CAAL was not satisfactory for all prepared samples. This observation was closely connected with which model drug was used; chlorhexidines are more effective against bacteria than against microorganisms (yeasts).

\section{Conclusion}

This study was aimed to prepare, test, and statistically evaluate mucoadhesive oral films based on the prospective mucoadhesive polymer carmellose in the form of its sodium salt and acid nonwoven textile. Films were formulated using two promising techniques: solvent casting and impregnation. Innovative nanotechnologically modified clay mineral (vermiculite) with intercalated antiseptic drugs, chlorhexidine diacetate and digluconate, was incorporated into their structure. Multivariate data analysis was used to evaluate the effects of the nonwoven textile and incorporation of the active substance on the physicomechanical, chemical, and 
mucoadhesive properties of formulated MOFs. These evaluations were complemented by testing of the antimicrobial and antimycotic activity of MOFs, which demonstrated the suitability of the prepared formulation for clinical use.

\section{Conflict of Interests}

The authors declare that there is no conflict of interests regarding the publication of this paper.

\section{Acknowledgments}

This work was supported by Ministry of Health of the Czech Republic (Project no. 1 RVO-FNOs/2012 and Project no. NT14477) and the IT4 Innovations Centre of Excellence (Project reg. no. CZ.1.05/1.1.00/02.0070). Authors also thank M. Heliová for SEM images and L. Pazourková for particle size analysis.

\section{References}

[1] S. Bertesteanu, S. Triaridis, M. Stankovic et al., "Polymicrobial wound infections: pathophysiology and current therapeutic approaches," International Journal of Pharmaceutics, vol. 463, no. 2, pp. 119-126, 2014.

[2] H. Young, J. Hirsh, E. M. Hammerberg, and C. S. Price, "Dental disease and periprosthetic joint infection," The Journal of Bone and Joint Surgery-American Volume, vol. 96, no. 2, pp. 162-168, 2014.

[3] E. Pasich, A. Bialecka, and J. Marcinkiewicz, "Efficacy of taurine haloamines and chlorhexidine against selected oral microbiome species," Medycyna Doświadczalna i Mikrobiologia, vol. 65, no. 3, pp. 187-196, 2013.

[4] A. Pinto and C. H. Hong, "Orofacial manifestations of bacterial and viral infections in children," Journal of the California Dental Association, vol. 41, pp. 271-279, 2013.

[5] R. A. Cawson, W. H. Binnie, A. W. Barrett, and J. M. Wright, Oral Disease: Clinical and Pathological Correlations, Mosby, Edinburgh, UK, 2001.

[6] D. Eisen and D. P. Lynch, The Mouth. Diagnosis and Treatment, Mosby, St. Louis, Mo, USA, 1998.

[7] F. Rivera-Hidalgo and T. W. Stanford, "Oral mucosal lesions caused by infective microorganisms I. Viruses and bacteria," Periodontology 2000, vol. 21, no. 1, pp. 106-124, 1999.

[8] R. V. Lalla, L. L. Patton, and A. Dongari-Bagtzoglou, "Oral candidiasis: pathogenesis, clinical presentation, diagnosis and treatment strategies," Journal of the California Dental Association, vol. 41, no. 4, pp. 263-268, 2013.

[9] L. Coronado-Castellote and Y. Jimenez-Soriano, "Clinical and microbiological diagnosis of oral candidiasis," Journal of Clinical and Experimental Dentistry, vol. 5, no. 5, pp. e279-e286, 2013.

[10] E. Dorko, A. Jenča, E. Pilipčinec, J. Danko, E. Švický, and L. Tkáčiková, "Candida-associated denture stomatitis," Folia Microbiologica (Praha), vol. 46, no. 5, pp. 443-446, 2001.

[11] K. S. Gurusamy, R. Koti, C. D. Toon, P. Wilson, and B. R. Davidson, "Antibiotic therapy for the treatment of methicillinresistant Staphylococcus aureus (MRSA) infections in surgical wounds," The Cochrane Database of Systematic Reviews, vol. 8, Article ID CD009726, 2013.
[12] M. ŠLširak, A. Zvizdić, and M. Hukić, "Methicillin-resistant staphylococcus aureus (MRSA) as a cause of nosocomial wound infections," Bosnian Journal of Basic Medical Sciences, vol. 10, no. 1, pp. 32-37, 2010.

[13] R. Bali, P. Sharma, S. Nagrath, and P. Gupta, "Microbial isolations from maxillofacial operation theatre and its correlation to fumigation in a teaching hospital in India," Journal of Maxillofacial and Oral Surgery, vol. 13, no. 2, pp. 128-132, 2014.

[14] N. Salamat-Miller, M. Chittchang, and T. P. Johnston, "The use of mucoadhesive polymers in buccal drug delivery," Advanced Drug Delivery Reviews, vol. 57, no. 11, pp. 1666-1691, 2005.

[15] A. V. Dubolazov, Z. S. Nurkeeva, G. A. Mun, and V. V. Khutoryanskiy, "Design of micoadhesive polymeric films based on blends of poly(acrylic acid) and (hydroxypropyl)cellulose," Biomacromolecules, vol. 7, no. 5, pp. 1637-1643, 2006.

[16] Y. Sudhakar, K. Kuotsu, and A. K. Bandyopadhyay, "Buccal bioadhesive drug delivery-a promising option for orally less efficient drugs," Journal of Controlled Release, vol. 114, no. 1, pp. 15-40, 2006.

[17] R. K. Averineni, S. G. Sunderajan, S. Mutalik et al., "Development of mucoadhesive buccal films for the treatment of oral sub-mucous fibrosis: a preliminary study," Pharmaceutical Development and Technology, vol. 14, no. 2, pp. 199-207, 2009.

[18] J. O. Morales and J. T. McConville, "Manufacture and characterization of mucoadhesive buccal films," European Journal of Pharmaceutics and Biopharmaceutics, vol. 77, no. 2, pp. 187-199, 2011.

[19] V. Prajapati, M. Bansal, and P. Kumar Sharma, "Mucoadhesive buccal patches and use of natural polymer in its preparation-a review," International Journal of PharmTech Research, vol. 4, no. 2, pp. 582-589, 2012.

[20] J. Gajdziok and D. Vetchý, "Mucoadhesive polymers in medical forms," Chemicke Listy, vol. 106, no. 7, pp. 632-638, 2012.

[21] D. Vetchý, H. Landová, J. Gajdziok, P. Doležel, Z. Daněk, and J. Štembírek, "Determination of dependencies among in vitro and in vivo properties of prepared mucoadhesive buccal films using multivariate data analysis," European Journal of Pharmaceutics and Biopharmaceutics, vol. 86, no. 3, pp. 498-506, 2014.

[22] M. I. Carretero and M. Pozo, "Clay and non-clay minerals in the pharmaceutical industry. Part I. Excipients and medical applications," Applied Clay Science, vol. 46, no. 1, pp. 73-80, 2009.

[23] M. I. Carretero and M. Pozo, "Clay and non-clay minerals in the pharmaceutical and cosmetic industries. Part II. Active ingredients," Applied Clay Science, vol. 47, no. 3-4, pp. 171-181, 2010.

[24] F. Bergaya, B. K. G. Theng, and G. Lagaly, Handbook of Clay Science, Elsevier, Oxford, UK, 2006.

[25] J. Madejová, "FTIR techniques in clay mineral studies," Vibrational Spectroscopy, vol. 31, no. 1, pp. 1-10, 2003.

[26] S. M. Magaña, P. Quintana, D. H. Aguilar et al., "Antibacterial activity of montmorillonites modified with silver," Journal of Molecular Catalysis A: Chemical, vol. 281, no. 1-2, pp. 192-199, 2008.

[27] K. Malachová, P. Praus, Z. Rybková, and O. Kozák, "Antibacterial and antifungal activities of silver, copper and zinc montmorillonites," Applied Clay Science, vol. 53, no. 4, pp. 642-645, 2011.

[28] M. Valášková, M. Hundáková, K. M. Kutláková et al., "Preparation and characterization of antibacterial silver/vermiculites and silver/montmorillonites," Geochimica et Cosmochimica Acta, vol. 74, no. 22, pp. 6287-6300, 2010. 
[29] C.-H. Hu and M.-S. Xia, "Adsorption and antibacterial effect of copper-exchanged montmorillonite on Escherichia coli $\mathrm{K}_{88}$," Applied Clay Science, vol. 31, no. 3-4, pp. 180-184, 2006.

[30] C. H. Hu, Y. Xu, M. S. Xia, L. Xiong, and Z. R. Xu, "Effects of $\mathrm{Cu}^{2+}$-exchanged montmorillonite on growth performance, microbial ecology and intestinal morphology of Nile tilapia (Oreochromis niloticus)," Aquaculture, vol. 270, no. 1-4, pp. 200206, 2007.

[31] S.-Z. Tan, K.-H. Zhang, L.-L. Zhang, Y.-S. Xie, and Y.-L. Liu, "Preparation and characterization of the antibacterial $\mathrm{Zn}^{2+}$ or/and $\mathrm{Ce}^{3+}$ loaded montmorillonites," Chinese Journal of Chemistry, vol. 26, no. 5, pp. 865-869, 2008.

[32] P. Herrera, R. C. Burghardt, and T. D. Phillips, "Adsorption of Salmonella enteritidis by cetylpyridinium-exchanged montmorillonite clays," Veterinary Microbiology, vol. 74, no. 3, pp. 259272, 2000.

[33] Y.-L. Ma, B. Yang, T. Guo, and L. Xie, "Antibacterial mechanism of $\mathrm{Cu}^{2+}-\mathrm{ZnO} /$ cetylpyridinium-montmorillonite in vitro," Applied Clay Science, vol. 50, no. 3, pp. 348-353, 2010.

[34] K. Malachová, P. Praus, Z. Pavlíčková, and M. Turicová, “Activity of antibacterial compounds immobilised on montmorillonite," Applied Clay Science, vol. 43, no. 3-4, pp. 364-368, 2009.

[35] G. Özdemir, M. H. Limoncu, and S. Yapar, "The antibacterial effect of heavy metal and cetylpridinium-exchanged montmorillonites," Applied Clay Science, vol. 48, no. 3, pp. 319-323, 2010.

[36] S. Holešová, M. Valášková, E. Plevová, E. Pazdziora, and K. Matějová, "Preparation of novel organovermiculites with antibacterial activity using chlorhexidine diacetate," Journal of Colloid and Interface Science, vol. 342, no. 2, pp. 593-597, 2010.

[37] S. Holešová, M. Samlíková, E. Pazdziora, and M. Valášková, "Antibacterial activity of organomontmorillonites and organovermiculites prepared using chlorhexidine diacetate," Applied Clay Science, vol. 83-84, pp. 17-23, 2013.

[38] V. A. Perumal, D. Lutchman, I. Mackraj, and T. Govender, "Formulation of monolayered films with drug and polymers of opposing solubilities," International Journal of Pharmaceutics, vol. 358, no. 1-2, pp. 184-191, 2008.

[39] M. A. Repka, S. L. Repka, and J. W. McGinity, "Bioadhesive hotmelt extruded film for topical and mucosal adhesion applications and drug delivery and process for preparation thereof," U.S. Patent; US6375963 B1, 2002.

[40] J. W. Lee, J. H. Park, and J. R. Robinson, "Bioadhesive-based dosage forms: the next generation," Journal of Pharmaceutical Sciences, vol. 89, no. 7, pp. 850-866, 2000.

[41] G. P. Andrews, T. P. Laverty, and D. S. Jones, "Mucoadhesive polymeric platforms for controlled drug delivery," European Journal of Pharmaceutics and Biopharmaceutics, vol. 71, no. 3, pp. 505-518, 2009.

[42] S. K. Roy and B. Prabhakar, "Bioadhesive polymeric platforms for transmucosal drug delivery systems-a review," Tropical Journal of Pharmaceutical Research, vol. 9, no. 1, pp. 91-104, 2010.

[43] N. V. S. Madhav, R. Semwal, D. K. Semwal, and R. B. Semwal, "Recent trends in oral transmucosal drug delivery systems: an emphasis on the soft palatal route," Expert Opinion on Drug Delivery, vol. 9, no. 6, pp. 629-647, 2012.

[44] J. Ding, R. He, G. Zhou, C. Tang, and C. Yin, "Multilayered mucoadhesive hydrogel films based on thiolated hyaluronic acid and polyvinylalcohol for insulin delivery," Acta Biomaterialia, vol. 8, no. 10, pp. 3643-3651, 2012.

[45] A. Bernkop-Schnürch, "Thiomers: a new generation of mucoadhesive polymers," Advanced Drug Delivery Reviews, vol. 57, no. 11, pp. 1569-1582, 2005.
[46] I. Rácz and J. Borsa, "Swelling of carboxymethylated cellulose fibres," Cellulose, vol. 4, no. 4, pp. 293-303, 1997.

[47] C. Barba, D. Montané, M. Rinaudo, and X. Farriol, "Synthesis and characterization of carboxymethylcelluloses (CMC) from non-wood fibers I. Accessibility of cellulose fibers and CMC synthesis," Cellulose, vol. 9, no. 3-4, pp. 319-326, 2002.

[48] Aqualon: Sodium Carboxymethylcellulose, Physical and Chemical Properties, 2000, http://www.ashland.com.

[49] W.-M. Kulicke, A. H. Kull, W. Kull, H. Thielking, J. Engelhardt, and J.-B. Pannek, "Characterization of aqueous carboxymethylcellulose solutions in terms of their molecular structure and its influence on rheological behaviour," Polymer, vol. 37, no. 13, pp. 2723-2731, 1996.

[50] D. Jain, E. Carvalho, and R. Banerjee, "Biodegradable hybrid polymeric membranes for ocular drug delivery," Acta Biomaterialia, vol. 6, no. 4, pp. 1370-1379, 2010.

[51] A. N. Prusov and S. M. Prusova, "Viscosity properties of aqueous solutions of carboxymethylcellulose and hydroxyethylcellulose blends," Fibre Chemistry, vol. 39, no. 1, pp. 12-15, 2007.

[52] T. Kube, M. Sutter, R. Trittler, N. Feltgen, L. L. Hansen, and H. T. Agostini, "Carboxymethylcellulose as a new carrier substance for intravitreal injection of reproducible amounts of triamcinolone," Graefe's Archive for Clinical and Experimental Ophthalmology, vol. 244, no. 11, pp. 1385-1390, 2006.

[53] H.-J. Cho, P. Balakrishnan, W.-S. Shim, S.-J. Chung, C.K. Shim, and D.-D. Kim, "Characterization and in vitro evaluation of freeze-dried microparticles composed of granisetron-cyclodextrin complex and carboxymethylcellulose for intranasal delivery," International Journal of Pharmaceutics, vol. 400, no. 1-2, pp. 59-65, 2010.

[54] H.-Y. Li, X. Song, and P. C. Seville, "The use of sodium carboxymethylcellulose in the preparation of spray-dried proteins for pulmonary drug delivery," European Journal of Pharmaceutical Sciences, vol. 40, no. 1, pp. 56-61, 2010.

[55] K. H. Esbensen, D. Guyot, F. Westad, and L. P. Houmøller, Multivariate Data Analysis-In Practice: An Introduction to Multivare Data Analysis and Experimental Design, CAMO Process AS, Oslo, Norway, 2004.

[56] S. Holešová, J. Štembírek, L. Bartošová et al., "Antibacterial efficiency of vermiculite/chlorhexidine nanocomposites and results of the in vivo test of harmlessness of vermiculite," Materials Science and Engineering C, vol. 42, pp. 466-473, 2014.

[57] European Directorate for the Quality of Medicines \& Health Care, The European Pharmacopoeia 8.0, European Directorate for the Quality of Medicines \& Health Care, Strasbourg, France, 8th edition, 2013, http://online6.edqm.eu/ep800/.

[58] N. A. Nafee, F. A. Ismail, N. A. Boraie, and L. M. Mortada, "Mucoadhesive delivery systems. I. Evaluation of mucoadhesive polymers for buccal tablet formulation," Drug Development and Industrial Pharmacy, vol. 30, no. 9, pp. 985-993, 2004.

[59] S. S. Shidhaye, N. S. Saindane, S. Sutar, and V. Kadam, "Mucoadhesive bilayered patches for administration of sumatriptan succinate," AAPS PharmSciTech, vol. 9, no. 3, pp. 909-916, 2008.

[60] J. Kneiflová, "Hodnocení baktericidní účinnosti dezinfekčních prostředků suspenzní mikrometodou," Československá Epidemiologie, Mikrobiologie, Imunologie, vol. 37, pp. 97-103, 1988.

[61] G. F. Walker, "Vermiculite minerals," in The X-Ray Identification and Crystal Structures of Clay Minerals, G. Brown, Ed., pp. 297324, The Mineralogical Society, London, UK, 1961.

[62] H. Shizoru and S. W. Bailey, "Crystal structure of a two-layer Mg-vermiculite," American Mineralogist, vol. 51, pp. 1124-1143, 1966. 
[63] C. de la Calle and H. Suquet, "Vermiculite," Reviews in Mineralogy and Geochemistry, vol. 19, pp. 455-496, 1988.

[64] V. C. Farmer, The Infrared Spectra of Minerals, The Mineralogical Society, London, UK, 1974.

[65] J. D. Russel and A. R. Fraser, "Infrared methods," in Clay Mineralogy: Spectroscopic and Chemical Determinative Methods, M. J. Wilson, Ed., pp. 11-67, Chapman \& Hall, CRC Press, London, UK, 1994.

[66] R. M. Silverstein, G. C. Basser, and T. C. Morrill, Spectrometric Identification of Organic Compounds, John Wiley \& Sons, New York, NY, USA, 1991.

[67] G. Socrates, Infrared and Raman Characteristic Group Frequencies, Tables and Charts, John Wiley \& Sons, Chichester, UK, 2001.

[68] R. P. Dixit and S. P. Puthli, "Oral strip technology: overview and future potential," Journal of Controlled Release, vol. 139, no. 2, pp. 94-107, 2009.

[69] A. B. Nair, R. Kumria, S. Harsha, M. Attimarad, B. E. AlDhubiab, and I. A. Alhaider, "In vitro techniques to evaluate buccal films," Journal of Controlled Release, vol. 166, no. 1, pp. 10-21, 2013.

[70] V. Kumar, G. Aggarwal, F. Zakir, and A. Choudhary, "Buccal bioadhesive drug delivery-a novel technique," International Journal of Pharmacy and Biological Sciences, vol. 1, pp. 89-102, 2011.

[71] Holzbecher, 2013, http://www.holzbecher.net.

[72] Y. Y. Tu, C. Y. Yuang, R. S. Chen, and M. H. Chen, "Effects of chlorhexidine on stem cells from exfoliated deciduous teeth," Journal of the Formosan Medical Association, vol. 114, no. 1, pp. 17-22, 2015.

[73] A. Puratchikody, V. V. Prasanth, S. T. Mathew, and B. A. Kumar, "Development and characterization of mucoadhesive patches of salbutamol sulfate for unidirectional buccal drug delivery," Acta Pharmaceutica, vol. 61, no. 2, pp. 157-170, 2011.

[74] R. Slezák, Preklinická parodontologie, NUCLEUS HK, Hradec Králové, Czech Republic, 2007.

[75] J. H. Macias, V. Arreguin, J. M. Munoz, J. A. Alvarez, J. L. Mosqueda, and A. E. Macias, "Chlorhexidine is a better antiseptic than povidone iodine and sodium hypochlorite because of its substantive effect," American Journal of Infection Control, vol. 41, no. 7, pp. 634-637, 2013. 

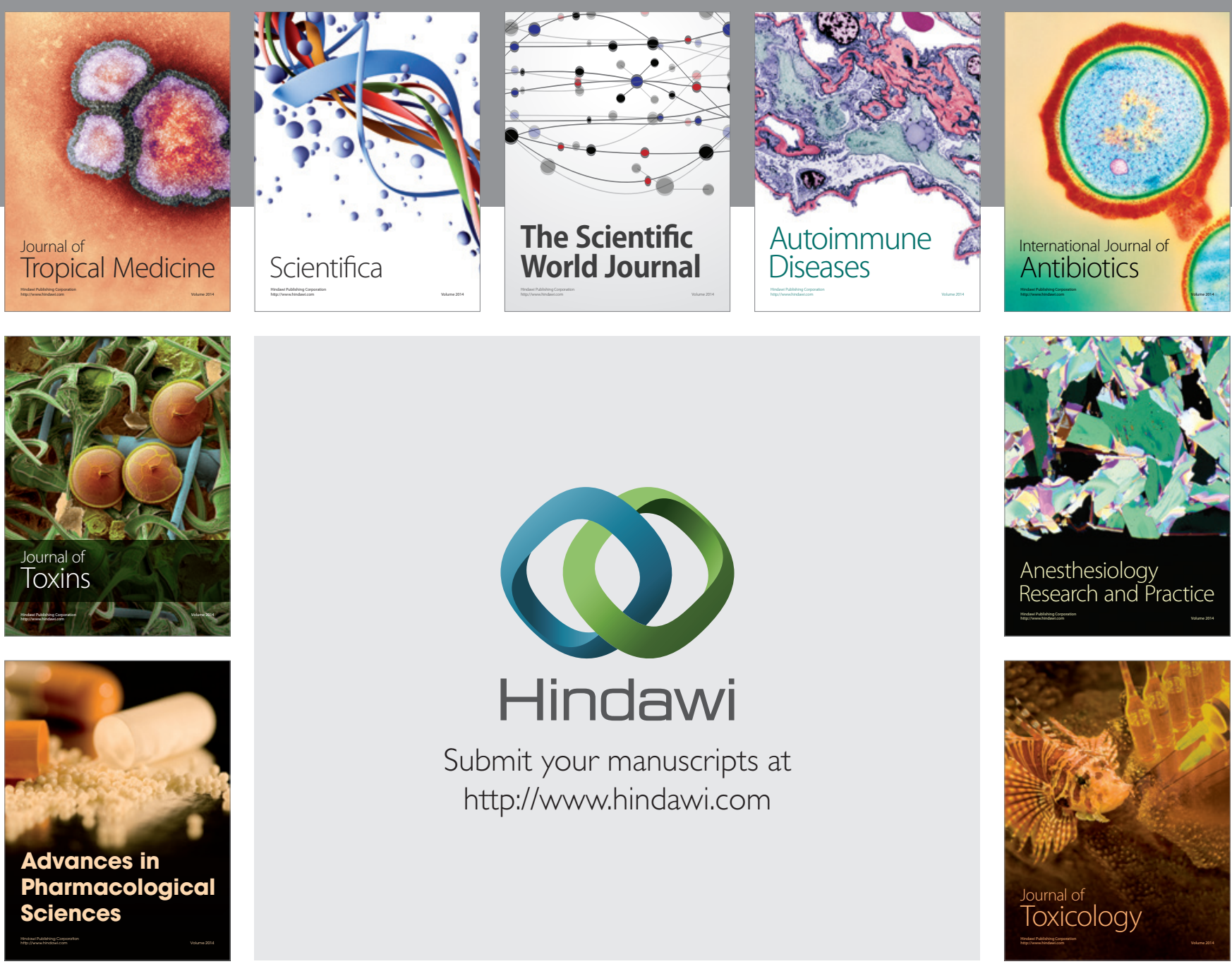

\section{Hindawi}

Submit your manuscripts at

http://www.hindawi.com
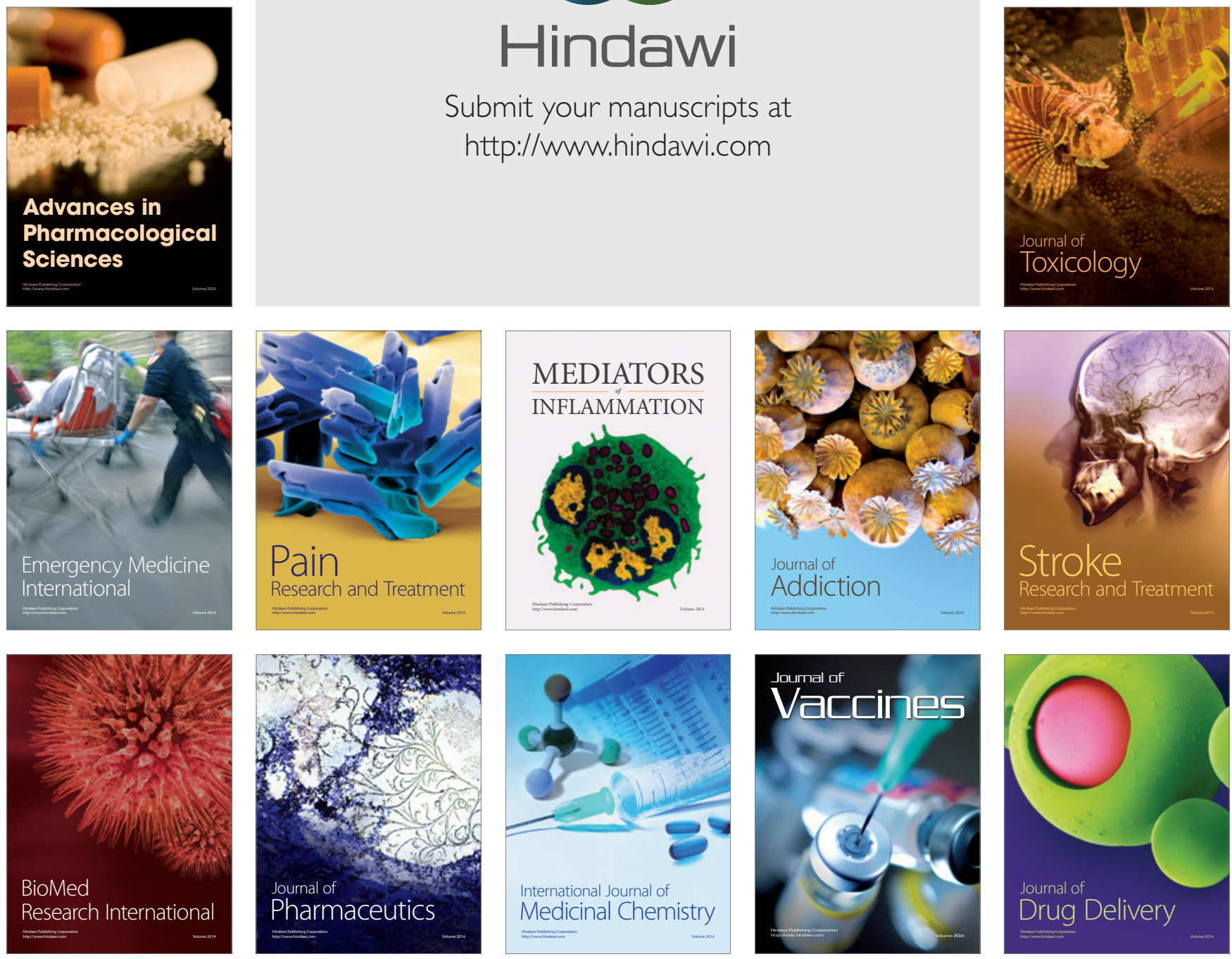